\title{
CLINICAL, MORPHOLOGICAL AND BIOCHEMICAL STUDIES OF A VIRILIZING TUMOR IN THE TESTIS*
}

\author{
BY KENNETH SAVARD, $\dagger$ RALPH I. DORFMAN, BILLY BAGGETT, $\ddagger$ LINDA L. \\ FIELDING, LEWIS L. ENGEL,§ HARRY T. MCPHERSON, LEONARD M. \\ LISTER,\| DAVID S. JOHNSON,đ EDWIN C. HAMBLEN AND \\ FRANK L. ENGEL
}

\author{
(From the Worcester Foundation for Experimental Biology, Shrewsbury, Mass.; The John \\ Collins Warren Laboratories, Collis P. Huntington Memorial Hospital of Harvard Uni- \\ versity at Massachusetts General Hospital, and the Department of Biological Chem- \\ istry, Harvard Medical School, Boston, Mass.; and the Departments of Medicine, \\ Obstetrics and Gynecology, and Pathology, Division of Endocrinology, \\ Duke University Medical Center, Durham, N. C.)
}

(Submitted for publication May 18, 1959; accepted November 12, 1959)

Although there is considerable indirect evidence indicating that virilizing testicular tumors exert their effects by producing androgenic steroid hormones, few attempts have been made to determine the exact nature of the compounds produced. One type of tumor which exerts particularly marked virilizing effects when found in prepubertal boys is that classified as an interstitial cell tumor of the testes (1-21). It has been well established that

\footnotetext{
* This work was supported by Contracts no. DA-49. 007-MD-184, Army Medical Research and Development Board, Office of the Surgeon General, Department of the Army; no. AT (30-1)-918, United States Atomic Energy Commission and a grant from the Charles A. King Trust. This is Publication no. 990 of the Cancer Commission of Harvard University and was supported by Grants no. CG-1393-C7 and C-2833-Cl, United States Public Health Service; P-95(T) American Cancer Society Inc.; and a grant from the Jane Coffin Childs Memorial Fund for Medical Research. Portions of the study on this case have been reported in abstract form in: Fed. Proc. 1956, 15, 346; J clin. Endocr. 1956, 16, 970 and 1629; Abstracts of the Twentieth International Physiological Congress, 1956, Brussels; Expos. ann. Biochim. méd. 1957, 12, 219; Southern Society for Clinical Research, January 25, 1958, New Orleans; Hormone Production in Endocrine Tumors, Ciba Found. Coll. Endocr. 1958, 12, 62.

† Investigator, Howard Hughes Medical Institute; present address: Departments of Biochemistry and Medicine, University of Miami School of Medicine, Miami, Fla.

$\$$ Present address : Department of Pharmacology, University of North Carolina School of Medicine, Chapel Hill, N. C.

$\S$ Permanent Faculty Fellow of the American Cancer Society.

|l Present address: University of Maryland School of Medicine, Baltimore, Md.

I Present address: Snodgrass Laboratory of Pathology and Bacteriology, St. Louis, Mo.
}

such tumors cause elevated levels of urinary 17ketosteroids. The morphology of these tumors leads one to predict that they are producing testosterone, since normal interstitial cells seem to have this function $(22,23)$. A few studies of the qualitative nature of the urinary steroids in patients with this type of tumor seem to confirm such a conclusion $(13,24)$. Accordingly, when the opportunity arose to study a patient bearing a testicular tumor thought to be of this type, it seemed worthwhile to attempt to establish the exact nature of the steroids produced. The study presented here was therefore undertaken.

This paper presents a description of the patient, histological observations on the tumor, the results of urinary steroid assays and the results of experiments in which slices of the tumor were incubated with $\mathrm{C}^{14}$-labeled steroid precursors.

\section{EXPERIMENTAL AND RESULTS}

\section{Clinical data}

D. W. (Duke no. D-99663), a 5-year-and-7-month old white male, was first seen at Duke Hospital on November 1,1954 , because of precocious growth and development, increasing libido, and personality changes. His birth and early development had been normal, but at 3 years of age progressive statural growth spurt and enlargement of the penis were noted. At 4 years of age, genital hair appeared, followed shortly by axillary, body and facial hair, mild facial acne and progressive deepening of the voice. During one year a gradual, painless enlargement of the right testis had been noted, accompanied by increasingly frequent penile erections and masturbation, apparently without ejaculation. The child became aggressive, somewhat withdrawn and uninterested in previous playmates and activities.

Physical examination revealed normal vital signs with a blood pressure of $112 / 60 \mathrm{~mm} \cdot \mathrm{Hg}$. His height was 135 


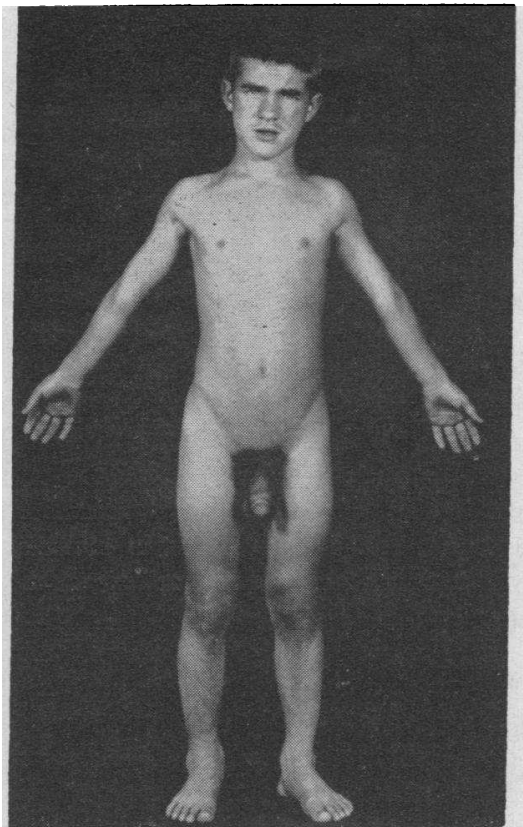

Fig. 1. The patient prior to operation; age, five YEARS AND SEVEN MONTHS.

$\mathrm{cm}$ and his weight $33.6 \mathrm{~kg}$. Anthropometric measurements corresponded to those of an average boy approximately 11 years of age. The muscular development was rather Herculean (Figure 1). The dental age was estimated to be 6.5 years. There was slight facial acne, moderate axillary hair, and abundant heavily pigmented and coarse pubic hair. Hirsutism was noted over the extremities, back and upper lip. The penis, in a flaccid state, measured $11.5 \mathrm{~cm}$ in circumference and $12.5 \mathrm{~cm}$ in length. The right testis was enlarged $(4.5 \times 3.7 \times 3.2$ $\mathrm{cm})$. It was uniformly abnormally firm, slightly irregular in contour and freely movable within the well rugated

TABLE I

Urinary steroid and gonadotropin excretion

\begin{tabular}{|c|c|c|c|}
\hline & \multirow[b]{2}{*}{ Preoperative } & \multicolumn{2}{|c|}{ Postoperative } \\
\hline & & 2 days & 1.5 years \\
\hline & $m g / 24 h r s$ & $m g / 24$ hrs & $m g / 24 h r s$ \\
\hline $\begin{array}{l}\text { 17-Ketosteroids }(25)^{*} \\
\text { Neutral acylable lipids }(26)^{*}\end{array}$ & $\begin{array}{l}13.6 \\
138\end{array}$ & 1.4 & 1.6 \\
\hline $\begin{array}{l}\text { Fluorogenic phenols }(27)^{*} \\
\text { Pregnanetriol } \dagger\end{array}$ & $\begin{array}{c}78 \\
4.1\end{array}$ & 80 & 13 \\
\hline Corticosteroids (28) $\ddagger$ & $<1.4$ & 1.1 & 1.1 \\
\hline
\end{tabular}

* Estimations carried out on extracts of urine boiled with 15 volumes per cent hydrochloric acid for ten minutes.

+ Carried out in the laboratory of Dr. Judson J. Van Wyk.

I Estimations carried out on extracts of urine incubated with mammalian $\beta$-glucuronidase (Ketodase, WarnerChilcott Laboratories) at $\mathrm{pH} 5.1$.

$\S$ Rat uterine units per 24 hours.
TABLE II

Urinary levels of individual 17-ketosteroids

\begin{tabular}{|c|c|c|}
\hline & Preoperative & $\begin{array}{c}\text { Postoperative } \\
2 \text { days }\end{array}$ \\
\hline Androsterone & $\begin{array}{c}m g / 24 h r s \\
2.4\end{array}$ & $\begin{array}{l}m g / 24 h r s \\
0\end{array}$ \\
\hline Etiocholanolone & 2.0 & 0.1 \\
\hline $\begin{array}{l}\text { Androstane-3,17-dione and } \\
\text { etiocholane- } 3,17 \text {-dione }\end{array}$ & 0.1 & 0.1 \\
\hline Dehydroepiandrosterone & 1.4 & 0 \\
\hline $\begin{array}{l}\text { 11 } \beta \text {-Hydroxyetiocholanolone } \\
\text { [and } \Delta^{9(11)} \text {-etiocholenolone ] }\end{array}$ & 0.2 & 0 \\
\hline 11-Ketoetiocholanolone & 0.2 & 0 \\
\hline $\begin{array}{l}\text { 11 } \beta \text {-Hydroxyandrosterone } \\
\left.\text { [and } \Delta^{9(11)} \text {-androstenolone }\right]\end{array}$ & 1.6 & 0 \\
\hline 11-Ketoandrosterone & 0.2 & 0.1 \\
\hline
\end{tabular}

and pigmented scrotum. The cord structures on that side were normal to palpation, and there was no local or distant lymphadenopathy. The left testis was normal in size, shape and consistency $(2 \times 0.7 \times 0.7 \mathrm{~cm})$. The prostate was enlarged and comparable in size to that of an adolescent. No other physical abnormalities were noted.

On psychological consultation the child was thought to be advanced both intellectually and in his social adjustments, corresponding approximately to the age of 8 years. The intelligence quotient was 135 and the social quotient 146.

The hemogram and urinalysis were normal, and the serological test for syphilis was negative. Blood chemical analyses (nonprotein nitrogen, total proteins and albumin/globulin ratio, fasting blood sugar, serum cholesterol and electrolytes) were normal. The basal metabolic rate was +3 per cent. X-rays of the chest and skull and intravenous pyelograms revealed no abnormali-

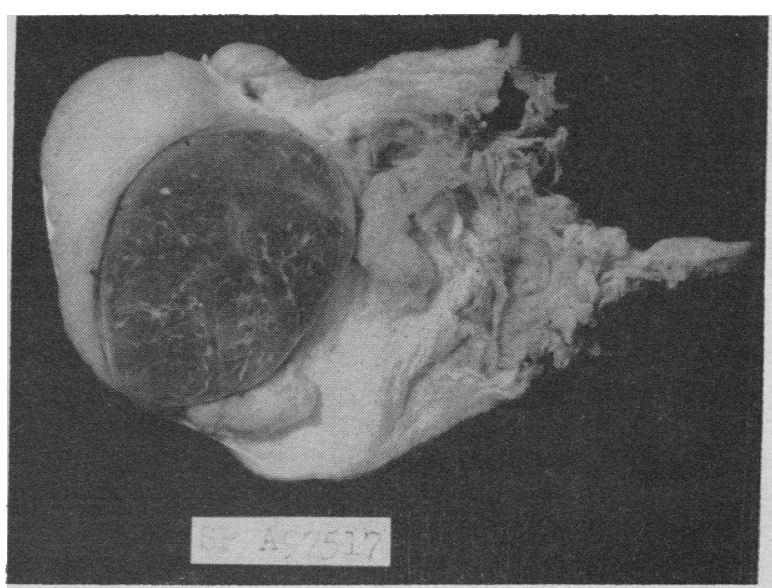

Fig. 2. THE SECTIONED SURFACE OF THE TUMOR, TESTIS AND CORD STRUCtURes are Illustrated. The identification tag is $2 \mathrm{~cm}$ in length. 


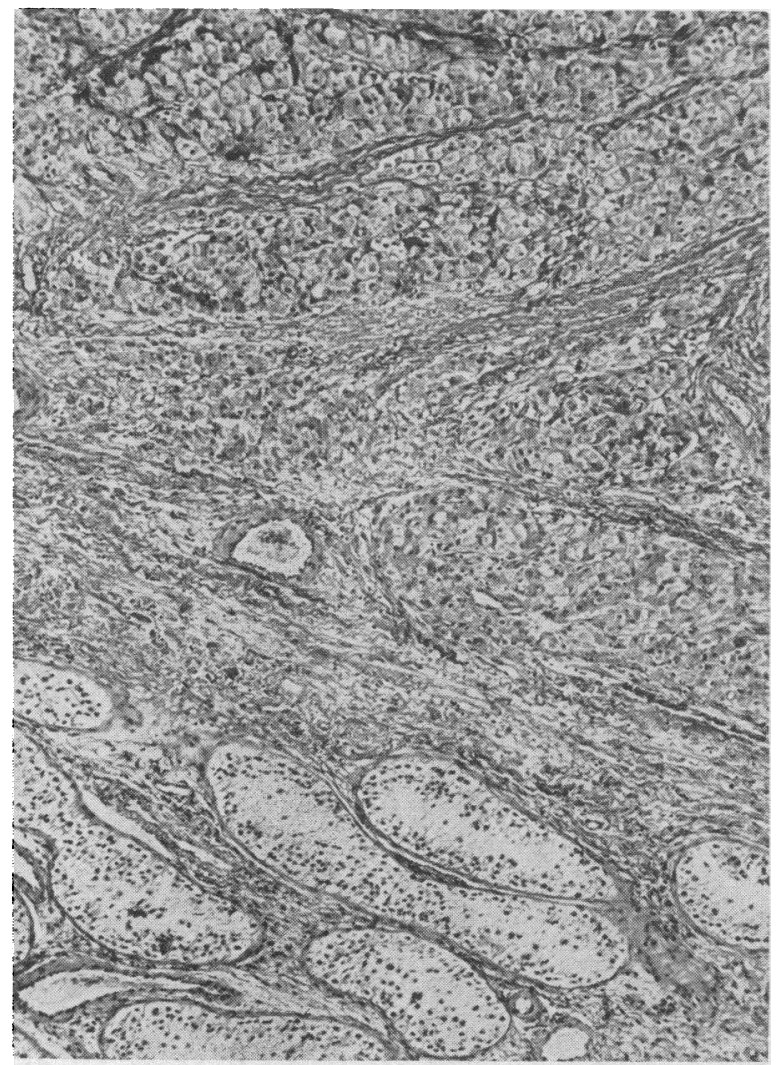

Fig. 3. THE MARGIN OF THE TUMOR IS SHOWN AT ITS JUNCTION WITH THE SURROUNDING NORMAL TESTICULAR TUbules. Note the fibrous septa dividing the tumor into lobules. (Hematoxylin and eosin, $\times 205$.)

ties. The bone age was greater than 10 but less than 14 years. Urinary steroid and gonadotropin analyses are reported below (Tables I and II).

On November 16, 1954, a right radical orchiectomy and biopsy of the left testis were performed.

Pathological anatomy. Gross: The right testis measured $2.5 \times 3.0 \times 3.5 \mathrm{~cm}$ and weighed $25 \mathrm{~g}$. On section a grossly well encapsulated, homogeneous soft tumor, lobulated by delicate fibrous septa, was observed (Figure 2). The sectioned surface of the tumor measured

- $23 \times 32 \mathrm{~mm}$, bulged and was dark brown with a distinct green cast. The surrounding testicular tissue was compressed.

Microscopic examination. There was an incomplete. thin connective tissue capsule. Where the capsule was incomplete, scattered small clumps of tumor cells extended for a short distance into the surrounding tissue. The tumor was made up of solid sheets of cells broken up by occasional thin, vascular, fibrous tissue septa (Figure 3). A delicate reticulum supporting framework further separated the tumor into clumps of 2 to 12 cells. The tumor cells were irregular, polyhedral in shape, 14 to $35 \mu$ in diameter (average, $22 \mu$ ), and occasionally had indistinct cell boundaries, although in most areas the cell boundaries were very clearly defined. Occasionally, syncytial masses of cytoplasm were formed with 2 to 5 nuclei. The nuclei were round, vesicular and showed no wrinkling of the nuclear membrane. There was a fine granular chromatin network with 1 to 3 prominent nucleoli. Occasional large hyperchromatic nuclei were present, but generally there was little variation and mitoses were rare. With Helly's fixation the cytoplasm was brightly eosinophilic, whereas with 10 per cent formalin fixation the cytoplasm appeared light pink with prominent unstained vacuoles.

The most striking cytological feature was the presence of a variety of cytoplasmic inclusions. With hematoxylin and eosin and Helly's fixation most of the cells showed very finely divided, granular, brown inclusions clustered about the nucleus (Figure 4). This material was indistinguishable from the "lipochrome" pigment present in normal interstitial cells; however, it was not sudanophilic, nor was there any sudanophilic material in any of the cells. This material reacted positively with the Schiff reagent and was particularly well demonstrated by phosphotungstic acid hematoxylin stains. A second type of cytoplasmic inclusion was present in most of the cells. These structures varied considerably in size measuring from 1.7 to $5.1 \mu$ in diameter. They were usually clus-

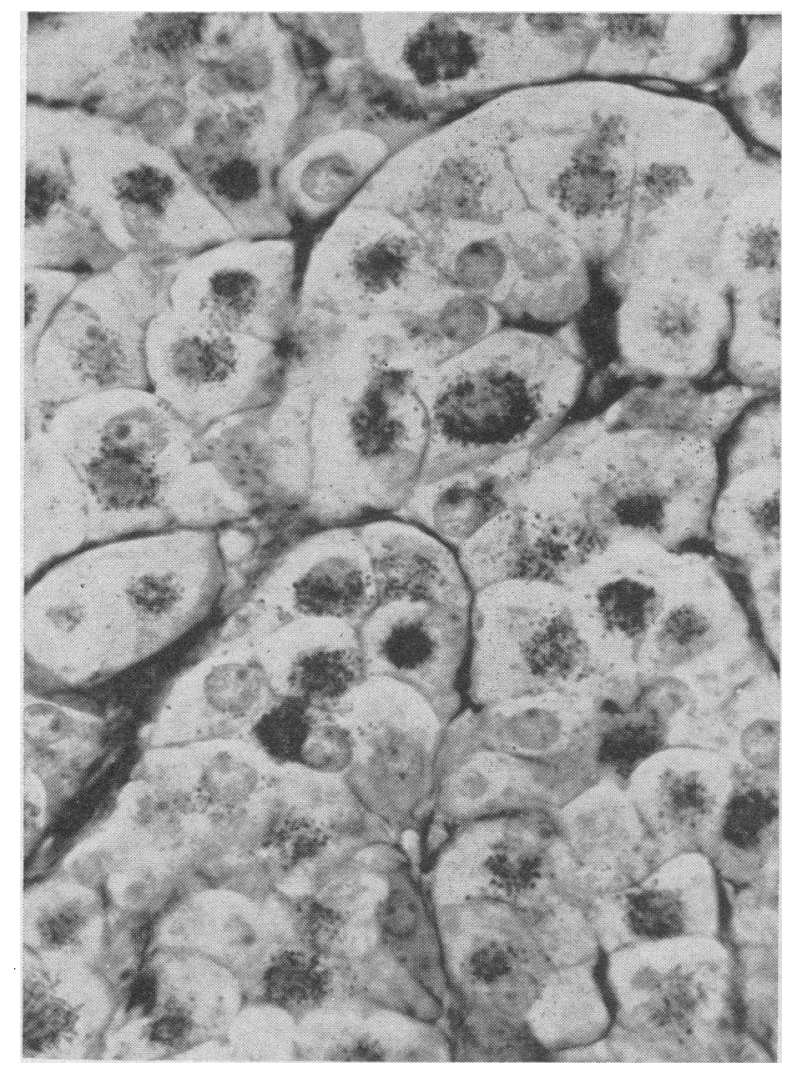

Fig. 4. This Microphotograph ILlUStrates The LIPOCHROME GRANULES CLUSTERED ABOUT THE NUCLEUS of Virtually eVery CEll. (Periodic acid-Schiff, $\times 1,021$.) 
tered about the periphery of the cytoplasm and occasionally filled the entire cell. They were highly refractile and were surrounded by a clear halo. Some of these granules had an internal structure in which the outer wall was stained dark blue with phosphotungstic acid hematoxylin. Just internal to this was a narrow, clear, unstained area. A solid mass of dark blue material made up the remainder of the inclusion. Others were solid and homogeneous. These were not well seen in formalin-fixed tissue by any technique used but were readily apparent in Helly-fixed tissue, particularly with Masson trichrome and phosphotungstic acid hematoxylin stains as well as with hematoxylin and eosin (Figure 5). A third type of inclusion was present, consisting of very rare rod-shaped structures which were indistinguishable from crystalloids of Reinke. Their most striking tinctorial reaction was their oxyphilia rendering them red with the Masson trichrome technique. Some of these were seen crossing a cell boundary and extending into an adjacent cell; others lay completely within the cytoplasm of a single cell (Figure 6).

The seminiferous tubules and interstitial cells of the left testis showed development corresponding to the patient's chronological age. There was no evidence of

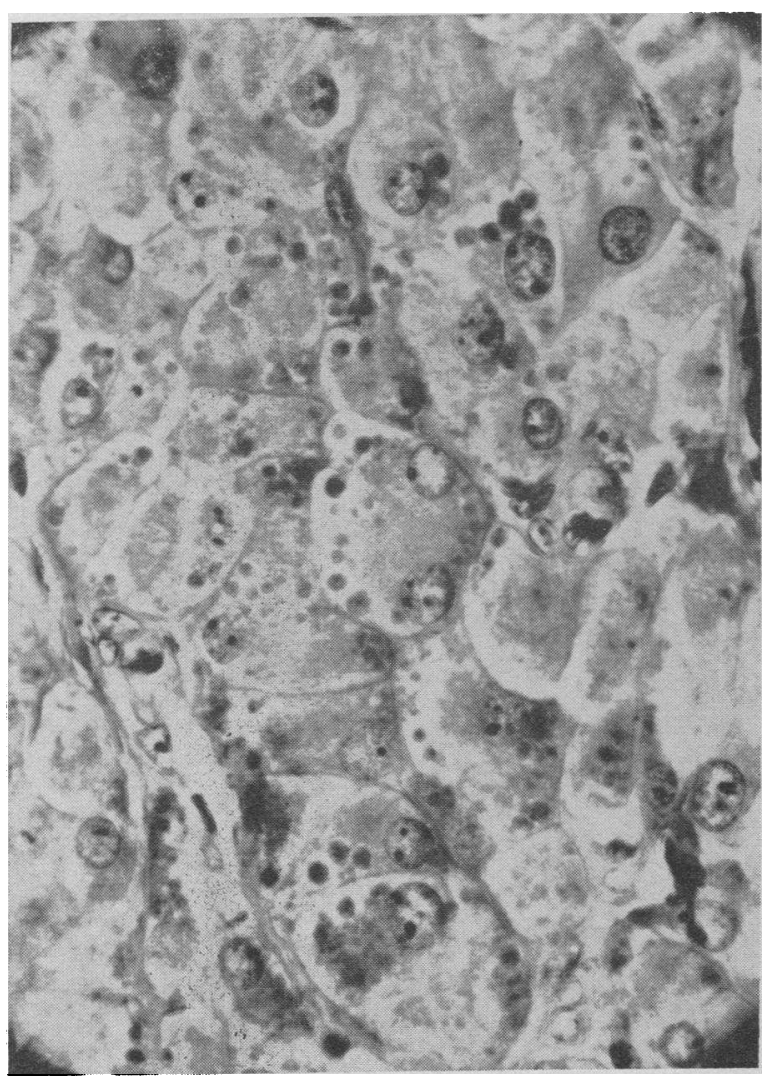

Fig. 5. LARGE CYTOPlasmic GRANULES CAN BE SEEN DISTRIBUTED ABOUT THE PERIPHERY OF THE TUMOR CELLS. Nuclear detail is also well shown. (Phosphotungstic acid hematoxylin, $\times 1,021$.)

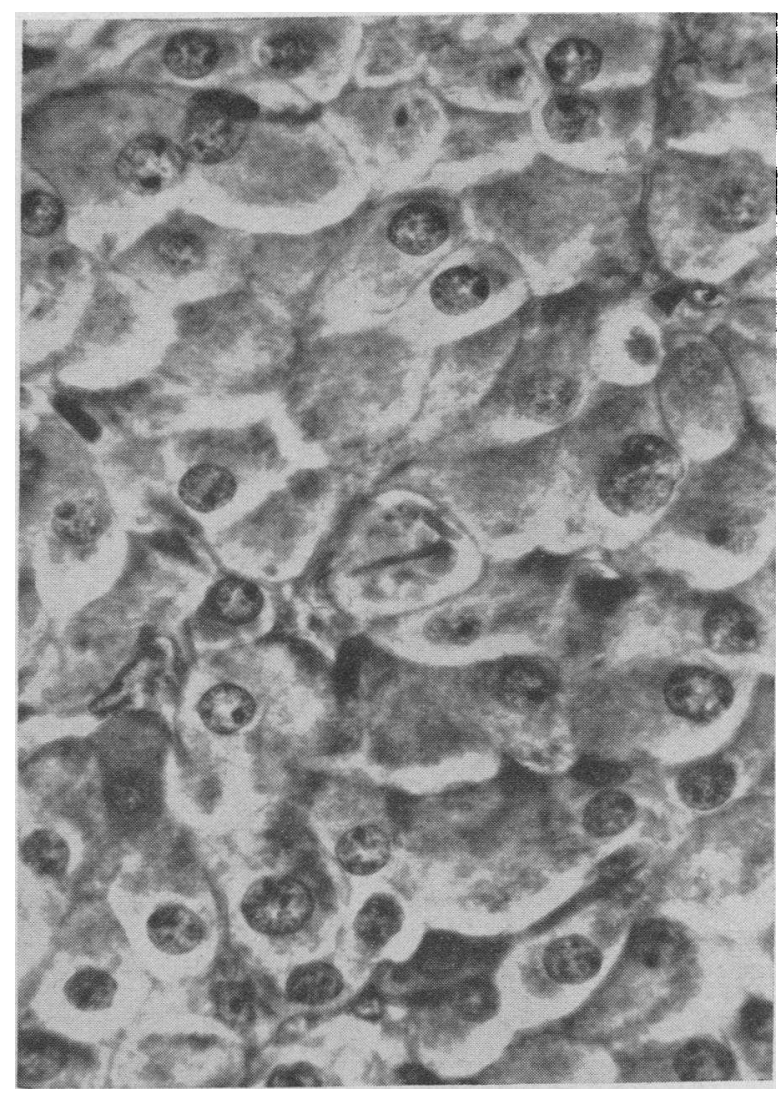

Fig. 6. THE CELL IN THE CENTER OF THE FIELd CONtains tWo ElONGATEd CRYSTALloIdS OF ReINKE. (Masson trichrome, $\times 1,021$.)

spermatogenesis. The pathological diagnosis was interstitial cell tumor of the right testis.

Follow'-up. Since discharge from the hospital there has been no regression in any of the somatic features previously depicted. In March and June, 1955, no. essential differences were noted. While the left testis was normal in size and consistency, the strong sexual drive persisted. The latter was considerably reduced by May, 1956, and the child's social adjustment was better. His height was $149 \mathrm{~cm}$ and his weight $39.5 \mathrm{~kg}$, gains of 14 $\mathrm{cm}$ and $5.9 \mathrm{~kg}$, respectively, since operation. At this time it was noted that the remaining left testis had grown remarkably in size in the preceding year, now measuring $5.5 \times 3 \mathrm{~cm}$. The testicular size, consistency and contour, and the prostate gland, were now comparable to that of a normal late-adolescent male. He was last seen in November, 1956, two years after surgery, with findings similar to those noted six months earlier except for a further gain of $6 \mathrm{~cm}$ in height. The bone age was estimated as 12 years, an advance of almost two years since operation. Daily urinary gonadotropin excretion was 7 rat uterine units, within the range for a normal adult. The postoperative urinary steroid and gonadotropin levels are recorded in Tables I and II. 


\section{Urinary steroids}

Estimations of steroid concentrations were carried out on 24-hour urine specimens collected before and at various periods after the removal of the tumor. The values obtained are shown in Table I. These values as well as those of gonadotropins are in agreement with values previously observed in this syndrome. The excretion of corticosteroids measured by the Silber and Porter method (28) was in the normal range for a 5 year old boy and was unchanged after removal of the tumor. Paper chromatograms of the corticosteroid fraction in the toluene/methanol: water $(75: 25)$ system (29) showed the presence of tetrahydrocortisone and tetrahydrocortisol as the preponderant corticosteroids before and after the operation. ${ }^{1}$ No unusual reducing compounds were detected.

The daily excretion of 17 -ketosteroids, neutral acylable lipids (hydroxysteroids) and pregnanetriol was elevated before removal of the tumor. A further sample of urine was boiled with 15 volumes per cent of hydrochloric acid, and the ether extracts were chromatographed in the Bush ligroin/methanol: water (96:4), and ligroin: toluene $(67: 33) /$ methanol-water $(70: 30)$ systems. The chromatograms were sprayed with Zimmermann reagent and the amount of each compound estimated by comparison of size and intensity of the spot with the sizes and intensities resulting from known amounts of the compound chromato-

1 The chemical names for the steroid compounds used in this paper are as follows : $3 \alpha$-hydroxyandrostan-17-one (androsterone) ; $3 \alpha, 11 \beta$-dihydroxyandrostan-17-one (11 $\beta$ hydroxyandrosterone) ; $11 \beta$-hydroxy - 4 -androstene -3,17dione (11 $\beta$-hydroxyandrostenedione); 4-androstene-3,11,17-trione (adrenosterone); 4-androstene-3,17-dione (androstenedione); $3 \alpha$-hydroxyetiocholane-17-one (etiocholanolone) ; $17 \beta$-hydroxy-4-androsten-3-one (testosterone) ; $11 \beta, 17 \beta$-dihydroxy-4-androsten-3-one (11 $\beta$-hydroxytestosterone) ; $17 \beta$-hydroxy-4-androstene-3,11-dione (11-ketotestosterone) ; $3 \beta$-hydroxy-5-androsten-17-one (dehydroepiandrosterone ); $3 \alpha, 17 \alpha, 21$-trihydroxypregnane-11,20-dione (tetrahydrocortisone); $3 \alpha, 11 \beta, 17 \alpha, 21$-tetrahydroxypregnan-20-one (tetrahydrocortisol); pregnane- $3 \alpha, 17 \alpha$,$20 \alpha$-triol (pregnanetriol) ; 4-pregnene-3,20-dione (progesterone) ; $17 \alpha$-hydroxy - 4 -pregnene-3,20-dione ( $17 \alpha$-hy droxyprogesterone); $11 \beta$-hydroxy -4-pregnene-3,20-dione (11 $\beta$-hydroxyprogesterone) ; $6 \beta$-hydroxy-4-pregnene-3,20dione $(6 \beta$-hydroxyprogesterone) ; $6 \beta$-acetoxy-4-pregnene3,20 -dione ( $6 \beta$-acetoxyprogesterone) ; $3 \beta$-hydroxy-5-pregnen-20-one (5-pregnenolone). graphed at the same time. This method has been found to be accurate within 15 per cent (30). The daily excretion of individual 17-ketosteroids estimated by this method is presented in Table II, in which the artifacts produced by the hydrolysis with acid are included with their known precursors.

Elevated excretion of both $\mathrm{C}_{19} \mathrm{O}_{2}$ and $\mathrm{C}_{19} \mathrm{O}_{3}$ compounds, androsterone and $11 \beta$-hydroxyandrosterone in particular, is to be noted. The excretion of all steroids measured after removal of the tumor was normal. The level of fluorogenic phenols gave no indication of elevated estrogen excretion and was unchanged by removal of the tumor; the reduction of this level 1.5 years after the tumor was removed is unexplained.

\section{In vitro studies}

The incubation of slices of this tumor was undertaken as a means of direct biochemical assessment of its steroid production. This technique utilizes small amounts of tissue and $\mathrm{C}^{14}$-labeled steroid precursors such as acetate-1- $\mathrm{C}^{14}$, and is one which is of proven value in this type of study (31). In order to facilitate extraction of the trace amounts of radioactive steroids from the incubation medium and tissue, it is necessary to add known amounts of crystalline nonradioactive steroids. In the case of each substance, the total steroid (radioactive and carrier) may then be isolated and purified and its radioactivity per milligram (specific activity) determined after suitable purification. By calculation back to the original weight of carrier, the amount of radioactivity associated with each carrier steroid may be ascertained. This in turn reflects the relative amount of each steroid formed during the experiment. Other methods for the microdetermination of the absolute amounts of endogenous steroid hormones present in endocrine glands have recently been developed (32-36) ; these however require exacting manipulations for certainty in the identification and quantitative measurement of the minute amounts of the compounds found. The incubation of specific $\mathrm{C}^{14}$-labeled steroids with tissues and the isolation of radioactive products, also by means of carrier dilution, provide an assessment of the tissue's capacity to effect certain specific transformations. 
The chemical methods employed consisted first in making a total lipid extract which was separated into nonpolar (fatty constituents, and so forth) and polar lipids. The latter fraction containing the carrier steroids was separated into acidic, phenolic and neutral polar lipids, and on occasion, into ketonic and nonketonic fractions. These procedures, described below in greater detail, afforded extracts containing the steroids relatively free from extraneous material. These extracts were then subjected to countercurrent distributions (ccd) and paper chromatographic separations in a variety of systems. Each steroid so isolated was free from steroidal and other contaminants, and was judged chemically pure by melting point and other criteria. The achievement of radiochemical purity required further procedures, which are described below.

\section{General \\ METHODS}

Countercurrent distributions. All 4- and 8-transfer distributions were carried out in separatory funnels. Lower layers were transferred, and equal volumes of the two phases were used. The 24-transfer distributions were carried out in a 25-tube, stainless steel Craig apparatus and those of greater numbers of transfers were carried out in the glass apparatus ( $\mathrm{H}$. O. Post Scientific Instrument Co.).

Paper chromatography. Chromatograms of the Zaffaroni type (37) and modifications $(38,39)$ were run at room temperature on Whatman no. 1 filter paper. In all systems employed, propylene glycol was used as the stationary phase. The following solvents were used as moving phases: ligroin (38), toluene (37), toluene: cyclohexane $(50: 50)$, and toluene: methyl cyclohexane (50:50) (39). Chromatograms of the type described by Bush (29) were run at $37^{\circ} \mathrm{C}$ on Whatman no. 2 filter paper.

Compounds were located on the developed chromatograms by visualization with ultraviolet light ( $\Delta^{4}-3$-ketosteroids), and by spraying with alkaline blue tetrazolium (reducing steroids) (40), alkaline $m$-dinitrobenzene (all ketosteroids) (38), or antimony trichloride reagent ( $\Delta^{5}-3 \beta$-hydroxysteroids) (41). After locating the steroids on the preparative chromatograms, the zones containing compounds or mixtures of compounds were cut out, cut into small pieces, and extracted repeatedly with hot methanol, then chloroform, or a mixture of equal parts of methanol and chloroform. The combined extracts were filtered to remove paper fibers and evaporated to dryness under reduced pressure. The extracts of paper previously saturated with propylene glycol were dissolved in chloroform and the chloroform washed several times with $1 / 10$ volumes of water to remove the glycol.
When required, zones of radioactivity on the chromatograms were located by means of contact radioautography. This consisted in placing the chromatogram (or a representative portion) in contact with Kodak Medical $\mathrm{X}$-ray film (no screen) for the required exposure time (42), and developing the film in the usual manner.

Measurement of radioactivity. All samples were plated at infinite thinness in metal dishes and counted in a windowless gas-flow counter. A minimum of 2,000 counts was accumulated on each. All counts were corrected for background.

Ultraviolet absorption. All ultraviolet absorption spectra and values of absorbance were measured in 95 per cent ethanol.

Formation of derivatives. Acetylations were carried out at room temperature with acetic anhydride and anhydrous pyridine $(1: 1)$; excess reagents were evaporated under a stream of air. Oxidations were carried out with chromium trioxide in glacial acetic acid at room temperature for two hours (43). Formation of oximes was carried out in the conventional way.

\section{Incubation}

The tumor was received within a few minutes of excision and chilled in cold physiological saline. It was sectioned and a representative portion used for the biochemical studies; the remainder was taken for pathology. Slices were prepared with a Stadie-Riggs slicer and distributed among four incubation flasks. These flasks contained as their final contents $0.93 \mathrm{~g}$ of tumor tissue, $20 \mathrm{ml}$ of fresh human serum, 0.02 mmole of potassium fumarate, $10 \mathrm{mg}$ of glucose, 500 units of pregnant mare serum gonadotropin (Equinex-Ayerst), 500 units of pregnancy urine gonadotropin (APL-Ayerst) and 5 units of porcine pituitary gonadotropin (FSH-Armour). The radioactive substances (the first three shown to be chromatographically homogeneous), added one to each flask, were: A) testosterone-4-C ${ }^{14}\left(0.92 \mathrm{mg}, 3.82 \times 10^{\circ}\right.$ $\mathrm{cpm})$; B) progesterone-4-C $\mathrm{C}^{14}(2 \mathrm{mg}, 350,000 \mathrm{cpm})$; C) cholesterol-4-C $C^{14}\left(2.2 \mathrm{mg}, 7.5 \times 10^{\circ} \mathrm{cpm}\right)$; and D) sodium acetate-1- $\mathrm{C}^{14}(1 \mathrm{mc})$; the radioacetate was added dissolved in water, and the steroids in $0.2 \mathrm{ml}$ of propylene glycol. Incubation was carried out with shaking for three hours at $37^{\circ} \mathrm{C}$ with 95 per cent $\mathrm{O}_{2}$ and 5 per cent $\mathrm{CO}_{2}$ as gas phase. The flask contents were frozen until analyzed.

\section{Addition of carrier steroids, extraction and prelimi- nary purification}

On removal of the incubation mixtures for storage, chromatographically pure steroids in varying amounts ( 5 to $20 \mathrm{mg}$ ) were added to each of the incubation flasks (Table III).

Each incubation mixture (tissue, medium and added carrier) was extracted individually in a Waring blendor with 25 volumes of chloroform: methanol $(2: 1)$ mixture (44). After removal of tissue debris by filtration, $1 / 5$ volume of water was added and the mixture shaken; the upper aqueous layer was removed and extracted twice with $1 / 2$ volume of chloroform. The combined lower 
TABLE III

Carrier steroids added to incubation mixtures

\begin{tabular}{|c|c|c|c|c|c|}
\hline \multirow[b]{3}{*}{ Steroids } & \multicolumn{5}{|c|}{ Experiment-Cle-substrate } \\
\hline & \multirow[b]{2}{*}{ A. Testosterone } & \multirow[b]{2}{*}{ B. Progesterone } & \multicolumn{2}{|c|}{ C. Cholesterol* } & \multirow[b]{2}{*}{ D. Acetate } \\
\hline & & & I & II & \\
\hline & $m g$ & $m g$ & $m g$ & $m g$ & $m g$ \\
\hline Estrone & & & & & 5 \\
\hline Estradiol-17 $\beta$ & & & & & 5 \\
\hline Estriol & & & & & 5 \\
\hline Testosterone & 10 & 10 & 20 & & 10 \\
\hline 4-Androstenedione & 10 & 10 & 20 & & 10 \\
\hline $11 \beta$-Hydroxyandrostenedione & 10 & $10 \dagger$ & 20 & & 10 \\
\hline $11 \beta$-Hydroxytestosterone & 10 & & 20 & & \\
\hline Adrenosterone & 10 & & & & $5 \dagger$ \\
\hline $\begin{array}{l}\text { Dehydroepiandrosterone } \\
5 \text {-Androstene- } 3 \beta, 17 \beta \text {-diol }\end{array}$ & & & & $\begin{array}{l}20 \\
20\end{array}$ & 10 \\
\hline Progesterone & & 10 & 20 & & 10 \\
\hline $17 \alpha$-Hydroxyprogesterone & & 10 & 20 & & $5 \dagger$ \\
\hline $11 \beta$-Hydroxyprogesterone & & $10 \dagger$ & & & $5 \dagger$ \\
\hline 11-Ketoprogesterone & & $10 \dagger$ & & & \\
\hline 5-Pregnenolone & & & & 20 & 10 \\
\hline $3 \beta, 17 \alpha$-Dihydroxy-5-pregnen-20-one & & & & 20 & \\
\hline $6 \beta$-Hydroxyprogesterone & & & & & $5 \dagger$ \\
\hline
\end{tabular}

* The extract from this incubation was divided into two equal parts; estrogens were added before the division and the two resulting phenolic fractions were combined later in the fractionation; other carriers were added after division of the extract.

$\dagger$ Added at a later stage in the fractionation procedure; for details see text.

layers were evaporated to dryness and the residue subjected to an 8-transfer ccd between ligroin (bp 65 to $75^{\circ} \mathrm{C}$ ) and 90 per cent aqueous methanol. The individual tubes from the distribution of each incubation were evaporated to dryness, weighed, assayed for radioactivity and for the carrier ketosteroids (by absorption at $240 \mathrm{~m} \mu$ or by the antimony trichloride reagent). The tubes containing the carrier steroids and associated radioactive polar material from each incubation were combined and dissolved in toluene. Each pooled sample was separated into the respective phenolic, acidic and neutral fractions by shaking the toluene solution with $1 \mathrm{~N}$ sodium hydroxide (27). The aqueous alkali solution was adjusted to $\mathrm{pH} 8.5$ and shaken with ether to remove the phenols. The neutral material remained in the toluene solution. The neutral polar fractions obtained in the incubations of testosterone (A), progesterone (B) and cholesterol (C) were subjected to a separation with Girard reagent $\mathrm{T}$ into ketonic and nonketonic fractions. The extract from the acetate-1-C $\mathrm{C}^{14}$ experiment (D) was not subjected to this separation.

\section{Separation and purification of carrier steroids}

Since somewhat different methods were used for the purification of the individual carrier steroids in each experiment, they will be discussed separately. The steps involved in establishing the radiochemical purity (45) of each apparently labeled compound will be presented for each compound. Where derivatives of the carriers were prepared (acetates, oximes, and so forth) the values of specific activity, unless otherwise noted, are not corrected for changes in molecular weight, and are given as determined.

\section{$V$. Incubation experiments}

EXPERIMENT A. Incubation of testosterone-4- $C^{14}$ : The ketonic fraction from this incubation was chromatographed in ligroin/propylene glycol for 96 hours. Each steroid carrier zone was located and recognized by its relative position (37), eluted and rechromatrographed. $17 \alpha$-Hydroxyprogesterone, testosterone and adrenosterone were not completely separated by this chromatography. Separation was carried out by acetylation of the mixture and the complete removal of testosterone acetate by chromatography in ligroin/propylene glycol; the two remaining steroids were separated by chromatography on paper in toluene: methyl cyclohexane $(50: 50) /$ propylene glycol.

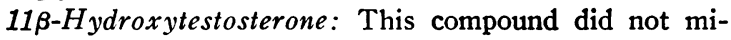
grate from the starting line as the free steroid in ligroin/ propylene glycol in 100 hours. It was chromatographed in toluene/propylene glycol for 12 hours to yield a contaminated product, $3.7 \mathrm{mg}$ in weight and specific activity $7,370 \mathrm{cpm}$ per $\mathrm{mg}$. One and two-tenths $\mathrm{mg}$ of this was diluted with $30 \mathrm{mg}$ of $11 \beta$-hydroxytestosterone carrier, acetylated, and chromatographed in ligroin/propylene glycol (24 hours), to provide a diluted $11 \beta$-hydroxytestosterone acetate $\left(\mathrm{mp} 151\right.$ to $152^{\circ} \mathrm{C}$, from acetone: hexane) with a specific activity of $114 \mathrm{cpm}$ per $\mathrm{mg}$ (or 129 corrected to the free compound). Oxidation with chromic acid and chromatography in ligroin/propylene glycol gave 11 -ketotestosterone acetate (mp 164 to $165^{\circ} \mathrm{C}$, acetone: hexane) with a specific activity of $112 \mathrm{cpm}$ per $\mathrm{mg}$ (127 as the free compound). Saponification with potassium carbonate in ethanol (46) gave 11-ketotestosterone $\left(\mathrm{mp} 184\right.$ to $\left.185^{\circ} \mathrm{C}\right)$; specific activity $131 \mathrm{cpm}$ per 
$\mathrm{mg}$ (130 as $11 \beta$-hydroxytestosterone). The specific activity of the initially isolated $11 \beta$-hydroxytestosterone was calculated as $3,300 \mathrm{cpm}$ per $\mathrm{mg}$; this value is used in the calculation of those data for this compound in Table IV.

11 $\beta$-Hydroxyandrostenedione: As initially isolated and crystallized ( $\mathrm{mp} 194^{\circ} \mathrm{C}$ ), this compound had a specific activity of $6,500 \mathrm{cpm}$ per $\mathrm{mg}$. Two samples of $0.5 \mathrm{mg}$ each were diluted with 50 and $70 \mathrm{mg}$ of carrier and purified as follows. Sample 1 was chromatographed (ligroin/ propylene glycol, 116 hours) and recrystallized from acetone: hexane (59 cpm per $\mathrm{mg}$ ); oxidized to adrenosterone, chromatographed, and recrystallized from methanol ( $\mathrm{mp} 220$ to $225^{\circ} \mathrm{C}$; $60 \mathrm{cpm}$ per $\mathrm{mg}$ ) ; recrystallized from acetone: hexane (mp 219 to $220^{\circ} \mathrm{C} ; 59 \mathrm{cpm}$ per $\mathrm{mg}$ ) ; converted to the dioxine and recrystallized from methanol (mp 209 to $210^{\circ} \mathrm{C}$; $56 \mathrm{cpm}$ per $\mathrm{mg}$, corrected to the molecular weight of adrenosterone). Sample 2 was chromatographed and crystallized (48 cpm per $\mathrm{mg}$ ); oxidation followed by chromatography and crystallization gave adrenosterone ( $\mathrm{mp} 218^{\circ} \mathrm{C} ; 46 \mathrm{cpm}$ per $\mathrm{mg}$ ). The initially isolated steroid was radiochemically pure at $6,500 \mathrm{cpm}$ per $\mathrm{mg}$.

Adrenosterone: As isolated and recrystallized (mp $212^{\circ} \mathrm{C}$ ) the specific activity was $278 \mathrm{cpm}$ per $\mathrm{mg}$ and as may be seen from the following, was slightly contaminated. The dioxime ( $\mathrm{mp} 222^{\circ} \mathrm{C} ; 258 \mathrm{cpm}$ per $\mathrm{mg}$ ) was chromatographed (toluene/propylene glycol, 34 hours) and recrystallized from methanol (mp 218 to $220^{\circ} \mathrm{C} ; 190$ cpm per mg, calculated as adrenosterone, $209 \mathrm{cpm}$ per $\mathrm{mg}$ ); the material in the mother liquor had the same specific activity. Adrenosterone was considered pure at $209 \mathrm{cpm}$ per $\mathrm{mg}$.

Androstenedione: This compound was recrystallized from ethyl acetate to give crystals (mp 172 to $173^{\circ} \mathrm{C}$; $19,700 \mathrm{cpm}$ per $\mathrm{mg}$ ) and a crystalline residue from the mother liquors $(17,400 \mathrm{cpm}$ per $\mathrm{mg})$. This product was not further manipulated and was considered radiochemically pure.

Testosterone: The original substrate, diluted as noted, was recovered ( $\mathrm{mp} 151$ to $152.5^{\circ} \mathrm{C} ; 250,000 \mathrm{cpm}$ per $\mathrm{mg}$ ).

Radioautography of the initial chromatograms having revealed no zones other than those associated with the above steroids, it is presumed that no other important transformations of testosterone occurred in this study. Total radioactivity associated with each carrier steroid at the above specific activities is given in Table IV, column $\mathrm{A}$, corrected to the amount present at the addition of the original carrier.

EXPERIMENT B. Incubation of progesterone-4- $C^{14}$ : The chromatography of the neutral ketonic fraction from this incubation was somewhat encumbered by the presence of a strongly fluorescing material whose presence seriously distorted the initial chromatograms in ligroin/ propylene glycol. In order to eliminate this material repeated chromatography was necessary; quantitative measurement of several carrier steroids showed that but 1.0 to $1.2 \mathrm{mg}$ remained. This was assumed to be true for all others and at this point additional amounts of each carrier were added $(10 \mathrm{mg})$ to the recombined fractions, and all were rechromatographed in ligroin/propylene glycol, and separated as described above; $11 \beta$-hy-

TABLE IV

Results of incubation studies*

\begin{tabular}{|c|c|c|c|c|c|c|}
\hline \multirow[b]{3}{*}{ Added carriers } & \multicolumn{6}{|c|}{ Experiment-CM-substrate } \\
\hline & \multicolumn{2}{|c|}{ A. Testosterone } & \multicolumn{2}{|c|}{ B. Progesterone } & \multicolumn{2}{|c|}{ D. Acetate } \\
\hline & $3.82 \times 10^{8}$ & cpm & $3.5 \times 10^{5}$ & $\mathrm{cpm}$ & $1.3 \times 10^{9}$ & cpm \\
\hline \multirow{11}{*}{$\begin{array}{l}\text { Estrone } \\
\text { Estradiol-17 } \beta \\
\text { Estriol } \\
\text { Testosterone } \\
\text { 4-Androstenedione } \\
11 \beta \text {-Hydroxyandrostenedione } \\
11 \beta \text {-Hydroxytestosterone } \\
\text { Adrenosterone } \\
\text { Dehydroepiandrosterone } \\
\text { 5-Androstene- } 3 \beta, 17 \beta \text {-diol } \\
\text { Progesterone } \\
17 \alpha \text {-Hydroxyprogesterone } \\
11 \beta \text {-Hydroxyprogesterone } \\
11-\text { Ketoprogesterone } \\
5 \text {-Pregnenolone } \\
3 \beta, 17 \alpha \text {-Dihydroxy-5-pregnen-20-one } \\
6 \beta \text {-Hydroxyprogesterone }\end{array}$} & \multirow{11}{*}{$\begin{array}{l}2.500 \times 10^{6} \\
0.197 \times 10^{6} \\
0.065 \times 10^{6} \\
0.033 \times 10^{6} \\
0.002 \times 10^{6}\end{array}$} & $\%$ & $c p m \dagger$ & $\%$ & $c p m$ & $\%$ \\
\hline & & & & & None & \\
\hline & & & & & None & \\
\hline & & \multirow{8}{*}{$\begin{array}{l}66.0 \\
5.0 \\
1.7 \\
0.8 \\
0.05\end{array}$} & $0.11 \times 10^{5}$ & 3.1 & $\begin{array}{l}\text { None } \\
0.30 \times 10^{5}\end{array}$ & 0.003 \\
\hline & & & $0.30 \times 10^{5}$ & 8.6 & $6.50 \times 10^{5}$ & 0.065 \\
\hline & & & $0.13 \times 10^{5}$ & $3.7 \ddagger$ & $3.47 \times 10^{5}$ & 0.035 \\
\hline & & & & & $\begin{array}{l}0.06 \times 10^{6} \\
0.04 \times 10^{6}\end{array}$ & $\begin{array}{l}0.0006 \ddagger \\
0.0004\end{array}$ \\
\hline & & & $2.03 \times 10^{5}$ & 58.0 & No & \\
\hline & & & $\begin{array}{l}1.14 \times 10^{5} \\
\text { None }\end{array}$ & 32.6 & $\begin{array}{l}0.63 \times 10^{5} \\
\text { None }\end{array}$ & $0.006 \ddagger$ \\
\hline & & & & & None & \\
\hline & & & & & None & \\
\hline Total & & 74 & & 106 & & 0.11 \\
\hline
\end{tabular}

* Amount of radioactivity and per cent of added substrate isolated by carrier-dilution. in the text.

$\ddagger$ This value is not comparable to others, as carrier was added late in the fractionation scheme. 
droxyandrostenedione, 11 $\beta$-hydroxy- and 11-ketoprogesterone were added at this point for the first time.

$11 \beta-H y d r o x y a n d r o s t e n e d i o n e:$ This compound was recognized as a transformation product of progesterone$\mathrm{C}^{14}$ late in the study and was seen first as a radioactive zone of slow mobility [slower than $11 \beta$-hydroxyprogesterone and $17 \alpha$-hydroxyprogesterone (38)]. To the material eluted from this radioactive area, $5 \mathrm{mg}$ of carrier $11 \beta$-hydroxyandrostenedione was added and the whole rechromatographed in ligroin/propylene glycol; the resulting zone was eluted and the steroid recrystallized from acetone: hexane to constant specific activity (mp 195.5 to $196.5^{\circ} \mathrm{C} ; 127 \mathrm{cpm}$ per $\mathrm{mg}$ ) ; $2.57 \mathrm{mg}$ of this material was diluted with $4.38 \mathrm{mg}$ of additional carrier and oxidized, chromatographed, and crystallized from methanol to give adrenosterone (mp 213 to $214^{\circ} \mathrm{C} ; 47 \mathrm{cpm}$ per $\mathrm{mg})$. The dioxime was formed and had a specific activity of $43 \mathrm{cpm}$ per $\mathrm{mg}$. The $11 \beta$-hydroxyandrostenedione obtained after the initial addition of carrier was considered radiochemically pure at approximately 127 cpm per mg. Comparison of specific activity with those of other isolated compounds is not valid because the carrier in this case was not added at the same stage as in the others. The total amount of this compound formed, shown as counts per minute in Table IV, must be considered minimal.

11 $\beta$-Hydroxyprogesterone: As isolated following the second addition of carriers, this compound $(14 \mathrm{mg})$ had a specific activity of $44 \mathrm{cpm}$ per $\mathrm{mg}$ but was contaminated with traces of $17 \alpha$-hydroxyprogesterone. Recrystallization from ethyl acetate gave $10.4 \mathrm{mg}$ ( $\mathrm{mp} 182.5$ to $183.5^{\circ} \mathrm{C} ; 8 \mathrm{cpm}$ per $\mathrm{mg}$ ). Oxidation with chromic acid followed by chromatography and crystallization from methanol gave 11-ketoprogesterone ( $\mathrm{mp} 170.5$ to $172.5^{\circ}$ C; $5 \mathrm{cpm}$ per $\mathrm{mg}$ ). Formation of the oxime and recrystallization (ethyl acetate) gave crystals (mp 226 to $229^{\circ} \mathrm{C}$ ) counting $2 \mathrm{cpm}$ per mg. 11 $\beta$-Hydroxyprogesterone was therefore considered to be devoid of significant radioactivity.

$17 \alpha-H y d r o x y$ progesterone: Nine and five-tenths $\mathrm{mg}$ of crystalline steroid was isolated counting $1,050 \mathrm{cpm}$ per $\mathrm{mg}$. Of this, $1.85 \mathrm{mg}$ was diluted with $18 \mathrm{mg}$ of additional carrier and the oxime formed and recrystallized from methanol ( $\mathrm{mp} 244$ to $246^{\circ} \mathrm{C}$ ). The oxime had a specific activity of $96 \mathrm{cpm}$ per $\mathrm{mg}$; the mother liquors yielded a residue which had essentially the same specific activity. $17 \alpha$-Hydroxyprogesterone was considered pure at $1,050 \mathrm{cpm}$ per $\mathrm{mg}$ specific activity.

Testosterone: Separated by chromatography from the above as the acetate ( $\mathrm{mp} 139.5$ to $\left.140.5^{\circ} \mathrm{C}\right)$, this compound counted $109 \mathrm{cpm}$ per $\mathrm{mg}$, and was slightly contaminated. Saponified to testosterone ( $\mathrm{mp} 149$ to $150^{\circ} \mathrm{C}$ ), the compound counted $104 \mathrm{cpm}$ per mg. Converted to testosterone oxime ( $\mathrm{mp} 212$ to $214.5^{\circ} \mathrm{C}$ ), the compound counted $95 \mathrm{cpm}$ per mg. Testosterone was therefore considered radiochemically pure at $104 \mathrm{cpm}$ per $\mathrm{mg}$.

11-Ketoprogesterone: This compound as isolated and crystallized (methanol, mp 171 to $172^{\circ} \mathrm{C}$ ) had a specific activity of $6 \mathrm{cpm}$ per mg. Formation of the oxime and crystallization eliminated the radioactivity.
Androstenedione: This compound was freed of most of its contaminating progesterone-4- $\mathrm{C}^{14}$ by the second chromatography in ligroin/propylene glycol. Recrystallization from ethyl acetate gave apparently contaminated crystals (mp 170.5 to $171^{\circ} \mathrm{C}$ ) with a specific activity of $319 \mathrm{cpm}$ per $\mathrm{mg}$; the semicrystalline residue from the mother liquors counted $260 \mathrm{cpm}$ per mg. The crystals, $7.1 \mathrm{mg}$, were treated to form the oxime ( $\mathrm{mp} 208$ to $210^{\circ}$ C; $202 \mathrm{cpm}$ per $\mathrm{mg}$ ), which was further purified by chromatography (toluene/propylene glycol, 25 hours) and crystallized ( $\mathrm{mp} 212$ to $213.5^{\circ} \mathrm{C}$ ). It counted $260 \mathrm{cpm}$ per $\mathrm{mg}$ with a similar specific activity in the mother liquor residue. Despite the variations in specific activities, no evidence of radioimpurities was apparent. The androstenedione was considered pure at a specific activity of $275 \mathrm{cpm}$ per mg.

Progesterone: The diluted substrate was recovered and recrystallized (acetone, $\mathrm{mp} 120$ to $120.5^{\circ} \mathrm{C}$ ). Its specific activity was $1,840 \mathrm{cpm}$ per $\mathrm{mg}$.

Radioautographs of the initial chromatograms revealed no zones of radioactivity other than those associated with the above compounds. The areas between progesterone and 4-androstenedione notably were free from radioactivity; the epimers $20 \alpha$ - and $20 \beta$-hydroxy-4-pregnen-3-ones, normal derivatives of progesterone in the ovary (34), have mobilities intermediate between those of the former compounds.

The data in Table IV for this Experiment B are calculated from the above specific activities and from the assumption that at the point of the second addition of carriers, $1.0 \mathrm{mg}$ of each of the original steroid carriers was present.

EXPERIMENT C. Incubation of cholesterol-4-C $C^{14}$ : The mixture from this incubation was extracted in the usual way. The chloroform: methanol extract obtained at the outset was halved and to the separate portions, I and II, were added the steroid carriers listed in Table III. Each portion was treated as described above (Section III. In vitro studies); the phenolic fractions from portions I and II were combined.

EXPERIMENT $C-I$. The total ketonic material from portion I containing the added $\alpha, \beta$-unsaturated ketosteroid carriers, weighed $122 \mathrm{mg}$ and contained $80,000 \mathrm{cpm}$. It was separated on paper chromatograms in ligroin/ propylene glycol as described in Experiments A and B.

$11 \beta-H y d r o x y$ testosterone: This compound as isolated, was rechromatographed in toluene/propylene glycol, acetylated, and the $11 \beta$-hydroxytestosterone acetate chromatographed in ligroin/propylene glycol. The purified steroid was recrystallized several times (acetone: hexane) and finally melted at 127 to $128^{\circ} \mathrm{C}$, and had a specific activity of $20 \mathrm{cpm}$ per $\mathrm{mg}$. The mother liquor residue counted $78 \mathrm{cpm}$ per $\mathrm{mg}$. The small amounts of substance precluded further manipulations and, therefore, definite radiochemical purity was not achieved.

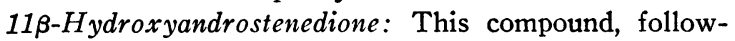
ing rechromatography in ligroin/propylene glycol (96 hours), was recrystallized from acetone: hexane to constant melting point (195 to $196^{\circ} \mathrm{C}$ ) and a specific activity of $71 \mathrm{cpm}$ per $\mathrm{mg}$ in the final crystals $(8.0 \mathrm{mg})$. 
Recrystallization from ethyl acetate : hexane gave crystals (5.6 mg, $69 \mathrm{cpm}$ per $\mathrm{mg}$ ) and an oily mother liquor residue $(1.5 \mathrm{mg})$ counting $156 \mathrm{cpm}$ per $\mathrm{mg}$, suggesting that radiochemical purity had not been achieved.

$17 \alpha-H y d r o x y p r o g e s t e r o n e:$ Following the separation of testosterone from this compound by the acetylation procedure, the $17 \alpha$-hydroxyprogesterone was rechromatographed several times in toluene: methyl cyclohexane (50:50)/propylene glycol and recrystallized from methanol to constant specific activity (50 cpm per $\mathrm{mg}$ ) of both the final crystals and mother liquor residue.

Testosterone: Isolated as the acetate, this compound counted $25 \mathrm{cpm}$ per $\mathrm{mg}$. The mother liquor was not studied.

Androstenedione: Isolated and purified by rechromatography, androstenedione failed to crystallize. The oily product had a specific activity of $110 \mathrm{cpm}$ per $\mathrm{mg}$; this value is considered maximal.

Progesterone: This compound, purified as in Experiment A, was crystallized from acetone. The progesterone as crystals (mp 119 to $120^{\circ} \mathrm{C}$ ) counted $193 \mathrm{cpm}$ per mg ; the progesterone as found in the last mother liquor counted $163 \mathrm{cpm}$ per mg. The radioactivity in this carrier, as in all others, was considered too low to warrant further attention, in contrast to the activities in Experiments $\mathrm{A}, \mathrm{B}$ and $\mathrm{D}$.

EXPERIMENT C-II. 5-Androstenediol: The nonketonic fraction of portion II, containing the carrier 5-androstenediol and its associated radioactivity, weighed $29 \mathrm{mg}$ and was chromatographed in toluene: methyl cyclohexane (50:50)/propylene glycol for 48 hours. The androstenediol was located (antimony trichloride reagent), eluted and the chromatography repeated. Crystallization of the eluted steroid (acetone: hexane) yielded $7.3 \mathrm{mg}$ of 5-androstenediol, $\mathrm{mp}$ to 175 to $177^{\circ} \mathrm{C}$, specific activity $90 \mathrm{cpm}$ per $\mathrm{mg}$. After further addition of carrier (14.3 $\mathrm{mg}$ ) to the above, the substance was acetylated and crystallized to give the diacetate, mp 157 to $158^{\circ} \mathrm{C}$, specific activity $14 \mathrm{cpm}$ per $\mathrm{mg}$. Recrystallization from acetone gave crystals and a residue in the mother liquors counting, respectively, 13 and $17 \mathrm{cpm}$ per $\mathrm{mg}$.

$3 \beta, 17 \alpha$-Dihydroxy-5-pregnen-20-one: The ketonic fraction weighing $45.8 \mathrm{mg}$ and containing $99,700 \mathrm{cpm}$, was dissolved in hot methanol and allowed to crystallize. Two crops of steroid were obtained, which were combined and recrystallized to constant melting point (226 to $236^{\circ} \mathrm{C}$ ) ; the last crystals had a specific activity of 90 cpm per mg. Acetylation and crystallization of the latter from acetone gave $5.7 \mathrm{mg}$ of $3 \beta, 17 \alpha$-dihydroxy-5pregnen-20-one acetate, mp 221 to $225^{\circ} \mathrm{C}$, specific activity $93 \mathrm{cpm}$ per $\mathrm{mg}$ and a mother liquor residue, 2.4 $\mathrm{mg}$ and $370 \mathrm{cpm}$ per $\mathrm{mg}$. Dilution of the crystals $(4.0$ $\mathrm{mg}$ ) with carrier steroid acetate $(4.0 \mathrm{mg})$ and recrystallization from acetone gave crystals $(4.7 \mathrm{mg})$ with a specific activity of $52 \mathrm{cpm}$ per $\mathrm{mg}$, which did not change on recrystallization from methanol. The two mother liquor residues from these steps (1.3 $\mathrm{mg}$ each), however, counted 108 and $72 \mathrm{cpm}$ per $\mathrm{mg}$, respectively. Thus, despite apparent constant specific activity of the crystals, the mother liquors gave evidence of radiochemical con- tamination. Further purification was not possible because of the lack of material.

Dehydroepiandrosterone and 5-pregnenolone: The total ketonic fraction, less the crystalline $3 \beta, 17 \alpha$-dihydroxy5-pregnen-20-one, containing $28,000 \mathrm{cpm}$, was chromatographed on paper in methyl cyclohexane/propylene glycol for 41 hours. Two zones were visualized by the antimony trichloride reagent, eluted, and each was rechromatographed in the same solvent system.

The slower zone which gave a positive Zimmermann reaction was crystallized from hexane to give dehydroepiandrosterone (190 cpm per $\mathrm{mg}$ ) which was diluted with an equal weight of carrier, acetylated and crystallized from hexane to give crystals counting $91 \mathrm{cpm}$ per mg. This material was recrystallized and the crystals obtained (mp 168 to $169^{\circ} \mathrm{C}$, corrected) counted $68 \mathrm{cpm}$ per $\mathrm{mg}$; the mother liquor residue counted $110 \mathrm{cpm}$ per mg. Recrystallization of $2.0 \mathrm{mg}$ of the crystals gave $0.8 \mathrm{mg}$ of specific activity $74 \mathrm{cpm}$ per $\mathrm{mg}$ and a new mother liquor residue $(0.7 \mathrm{mg})$ counting $140 \mathrm{cpm}$ per mg. Radiochemical purity could not, therefore, be demonstrated.

The faster zone was eluted, and after addition of carrier steroid $(10.9 \mathrm{mg})$, was recrystallized to constant melting point $\left(186\right.$ to $188^{\circ} \mathrm{C}$ ) and a final specific activity of $208 \mathrm{cpm}$ per $\mathrm{mg}$; the mother liquor residues were at each step of higher specific activity. Acetylation and crystallization from methanol gave crystals of pregnenolone acetate ( $\mathrm{mp} 148$ to $149^{\circ} \mathrm{C}$ ), whose specific activity was $125 \mathrm{cpm}$ per $\mathrm{mg}$; crystallized once more, the acetate counted $70 \mathrm{cpm}$ per $\mathrm{mg}$. The two last mother liquor residues counted 290 and $750 \mathrm{cpm}$ per mg, respectively. The product was considered contaminated.

In contrast to Experiments $\mathrm{A}, \mathrm{B}$ and $\mathrm{D}$, little radioactivity was associated with the above steroid carriers at the point of their isolation from the chromatograms. This low radioactivity precluded the further addition of carrier-diluent and prevented use of recrystallization procedures for demonstrating and achieving radiochemical purity. The uncharacterized radioactivity present in the extracts was not associated with any chromatographically discrete compounds; it tended to smear throughout the paper chromatograms of both Experiments C-I and C-II. Whether this material is a product of a biochemical transformation cannot be inferred from this study; it may be entirely due to artifact formation caused by the manipulatory procedures. The values obtained in this study have not been included in the tabulation of the results from the other three studies (Table IV).

EXPERIMENT D. Incubation of acetate-1-C $C^{44}$ : The polar lipids [tubes 5 to 8 from the distribution between ligroin and methanol : water $(90: 10)]$ were combined $(2.62 \times$ $10^{6} \mathrm{cpm}$ ) and washed free of acetate-1-C $\mathrm{C}^{14}$ by means of a 4-transfer ccd between water and chloroform, using the stripping procedure described by Weisiger (47). The upper phase of tube $O$ was saturated aqueous sodium acetate ( $\mathrm{pH} \mathrm{7.0)}$ instead of water. The resulting lipid fraction contained $2.68 \times 10^{6} \mathrm{cpm}$; apparently no appreciable amount of labeled acetate was present. This fraction was subjected to a phenolic separation (27), giving a 
neutral fraction containing $2.20 \times 10^{\circ} \mathrm{cpm}$ and a phenolic fraction $(86,000 \mathrm{cpm})$ which was subjected to a ccd between toluene and $1 \mathrm{~N}$ sodium hydroxide, using five funnels and complete stripping. There was a peak in radioactivity which moved with the alkali and was extractable with ether at $\mathrm{pH}$ 8.5. The material in this peak, having the properties of phenols, contained 15,000 cpm. This purified phenolic fraction was subjected to a 99-transfer ccd in methanol: water $(70: 30) /$ chloroform: carbon tetrachloride $(40: 60)$. The distribution was analyzed for radioactivity and for the estrogens by the fluorimetric method. Estrone, estradiol-17 $\beta$, and estriol were identified, but no peak in radioactivity was associated with any of the three estrogens. It was therefore concluded that none of the three was labeled.

Five $\mathrm{mg}$ each of $17 \alpha$-hydroxyprogesterone, $11 \beta$-hydroxyprogesterone, $6 \beta$-hydroxyprogesterone and adrenosterone were added as additional carriers to the neutral fraction. This was subjected to a 150-transfer ccd in cyclohexane: ethyl acetate $(50: 50) /$ ethanol: water (50: $50)$. The peaks of radioactivity $\left(\mathrm{K}^{2}=0.32\right.$ and $\mathrm{K}=$ 1.02) contained all of the neutral carrier steroids except progesterone and 5-pregnenolone which were found together in an area containing no peak of radioactivity $(\mathrm{K}=2.56)$. It was, therefore, concluded that these latter two compounds were not appreciably labeled.

The contents of the tubes in each of the two peaks of radioactivity containing the steroid carriers were combined, resulting in a pool of polar $(\mathrm{K}=0.32)$ material (Pool A) and one of less polar $(K=1.02)$ material (Pool B). Pool A contained all of the $11 \beta$-hydroxyandrostenedione and adrenosterone. Pool B contained all of the androstenedione, dehydroepiandrosterone, and $17 \alpha$-hydroxyprogesterone; each pool contained part of the $6 \beta$-hydroxyprogesterone, $11 \beta$-hydroxyprogesterone and testosterone. Pool A was acetylated and chromatographed in the cyclohexane: toluene $(50: 50) /$ propylene glycol system. Four zones were located on the chromatogram and eluted. These contained $11 \beta$-hydroxyandrostenedione, $11 \beta$-hydroxyprogesterone, adrenosterone, and a mixture of testosterone acetate and $6 \beta$-acetoxyprogesterone. This mixture of acetates was saponified with $1 \mathrm{~N}$ potassium hydroxide in methanol overnight at room temperature. The saponified material was chromatographed in the ligroin: toluene $(67: 33) /$ methanol: water $(70: 30)$ system. Three zones were located and eluted : testosterone, $6 \beta$-hydroxyprogesterone, and a less polar compound having the $R_{F}$ of allopregnane-3,6,20-trione, the major product of saponification of $6 \beta$-acetoxyprogesterone with excess alkali (48).

Pool B was subjected to a digitonin separation (49). The " $\beta$-fraction" was chromatographed in the ligroin: toluene $(67: 33) /$ methanol: water $(70: 30)$ system to yield dehydroepiandrosterone. The " $\alpha$-fraction" was acetylated and chromatographed in the ligroin/propylene glycol system. Three zones were located on the chromatogram and eluted; they were androstenedione, a mixture of $11 \beta$-hydroxyprogesterone and $17 \alpha$-hydroxypro-

${ }^{2} \mathrm{~K}=$ distribution coefficient. gesterone; and a mixture of the acetates of testosterone and $6 \beta$-hydroxyprogesterone. The mixture of $11 \beta$-hydroxyprogesterone and $17 \alpha$-hydroxyprogesterone was resolved in the ligroin:toluene $(67: 33) /$ methanol: water $(70: 30)$ system. The mixture of acetates of testosterone and $6 \beta$-hydroxyprogesterone was saponified and chromatographed in the same way as the corresponding fraction from Pool A. Again testosterone, 6 $\beta$-hydroxyprogesterone, and allopregnane-3,6,20-trione were recovered.

At this point, all of the carriers from the two peaks of radioactivity in the 150 -transfer ccd had been recovered chromatographically pure. In the cases in which the compound was recovered in both pools, the two portions were combined. Each carrier isolated was assayed for weight and radioactivity; additional unlabeled carrier was then added to each, and tests of radiochemical purity were applied. The details of these procedures are given for each compound.

11ß-Hydroxyandrostenedione: Analysis by ultraviolet absorption at $240 \mathrm{~m} \mu$ showed a recovery of $3.11 \mathrm{mg}$ containing $109,000 \mathrm{cpm}$. An additional $50 \mathrm{mg}$ of carrier was added and this was crystallized three times from aqueous ethanol yielding crystals having specific activities of $1,890,1,850$, and $1,880 \mathrm{cpm}$ per $\mathrm{mg}$ (calculated, 2,050 cpm per $\mathrm{mg}$ ) and a final mother liquor residue, specific activity $1,660 \mathrm{cpm}$ per $\mathrm{mg}$. Crystallization from benzene yielded crystals having a specific activity of $1,850 \mathrm{cpm}$ per $\mathrm{mg}$, and a mother liquor residue of $1,920 \mathrm{cpm}$ per mg. The crystals from benezene were subjected to a $99-$ transfer ccd in methanol: water $(70: 30) /$ chloroform: carbon tetrachloride $(20: 80)$. The single peak in radioactivity coincided with the peak in material having ultraviolet $(240 \mathrm{~m} \mu)$ absorption $(\mathrm{K}=0.73)$, and there was no evidence of lack of homogeneity (45). The mean specific activity in the region of the peak was 2,120 \pm 218 (standard deviation) cpm per mg. 11 $\beta$-Hydroxyandrostenedione was considered radiochemically pure at this point.

Adrenosterone: The adrenosterone isolated was measured by ultraviolet absorption $(238 \mathrm{~m} \mu)$, and contained $2.66 \mathrm{mg}$ and $32,000 \mathrm{cpm}$. An additional $10 \mathrm{mg}$ of unlabeled adrenosterone was added and a 99-transfer ccd was carried out using methanol: water $(70: 30) /$ chloroform: carbon tetrachloride $(10: 90)$. Analysis by ultraviolet absorption showed a single peak $(K=0.62)$, but radioactivity extended from tube $O$ through the peak in adrenosterone, thereby demonstrating lack of purity. The contents of the tubes containing the adrenosterone were pooled and crystallized four times from aqueous ethanol, yielding crystals having specific activities at each step of 395, 300, 279, and $289 \mathrm{cpm}$ per $\mathrm{mg}$ and a residue in the last mother liquor, specific activity of $308 \mathrm{cpm}$ per mg. Crystallization from ethyl acetate: hexane gave crystals, specific activity $275 \mathrm{cpm}$ per $\mathrm{mg}$ and a mother liquor residue of specific activity $264 \mathrm{cpm}$ per mg. The final crystals and residue in the mother liquor were combined and subjected to a 49-transfer ccd in cyclohexane: ethyl acetate $(60: 40) /$ ethanol: water $(50: 50)$. The single peak in radioactivity coincided with the single peak in material absorbing at $238 \mathrm{~m} \mu$ 
$(\mathrm{K}=0.71)$. The material was radiochemically pure as judged by the specific activity in the region of the peak which was constant at $277 \pm 24 \mathrm{cpm}$ per $\mathrm{mg}$. The adrenosterone was considered radiochemically pure.

$11 \beta$-Hydroxyprogesterone: The $11 \beta$-hydroxyprogesterone isolated was analyzed by ultraviolet absorption at $242 \mathrm{~m} \mu$, and consisted of $3.08 \mathrm{mg}$ and $24,000 \mathrm{cpm} ; 10 \mathrm{mg}$ of carrier was added. A 99-transfer ccd in methanol: water $(70: 30) /$ chloroform: carbon tetrachloride $(20: 80)$ showed a clear dissociation of radioactivity $(K=0.30)$ from the $11 \beta$-hydroxyprogesterone as measured by ultraviolet absorption $(\mathrm{K}=0.41)$. Hence, the $11 \beta$-hydroxyprogesterone was not labeled.

$6 \beta$-Hydroxyprogesterone: The portion of the $6 \beta$-hydroxyprogesterone carrier recovered unchanged was rechromatographed in ligroin: toluene $(67: 33) /$ methanol: water $(70: 30)$. The compound as isolated from this chromatogram was still not pure, as shown by an atypical ultraviolet absorption spectrum. The absorbance at 237 $\mathrm{m} \mu$ indicated a maximum content of $0.13 \mathrm{mg}$; it contained $950 \mathrm{cpm}$. To this was added $8.6 \mathrm{mg}$ of unlabeled carrier. A 99-transfer ccd in methanol: water $(80: 20)$ / chloroform: carbon tetrachloride $(10: 90)$ showed a clear dissociation of the radioactivity $(K=1.57)$ from the carrier $(\mathrm{K}=1.41)$. The transformation product of $6 \beta$-hydroxyprogesterone, allopregnane-3,6,20-trione, as recovered from the chromatograms, contained only $3,700 \mathrm{cpm}$. This low level of radioactivity together with the lack of activity in the small amount of $6 \beta$-hydroxyprogesterone recovered made further work on this fraction seem unwarranted.

Androstenedione: The pool of this compound recovered from the incubation mixture contained $2.04 \mathrm{mg}$ as measured by ultraviolet absorption at $240 \mathrm{~m} \mu$, and $133,000 \mathrm{cpm}$. To this was added $60 \mathrm{mg}$ of unlabeled androstenedione. Two crystallizations from aqueous ethanol furnished crystals having specific activities of 1,980 and 1,900 cpm per mg (calculated 2,140 cpm per $\mathrm{mg}$ ) and a final mother liquor, specific activity of $1,960 \mathrm{cpm}$ per $\mathrm{mg}$. Crystallization from acetone: cyclohexane yielded crystals of specific activity $1,880 \mathrm{cpm}$ per $\mathrm{mg}$ and a mother liquor residue of $1,960 \mathrm{cpm}$ per $\mathrm{mg}$. These latter crystals were subjected to a 99-transfer ccd in methanol: water $(80: 20) /$ carbon tetrachloride. The single peak in radioactivity coincided with the peak in ultraviolet absorption $(\mathrm{K}=0.72)$; the mean specific activity in the region of the peak was $2,130 \pm 194 \mathrm{cpm}$ per $\mathrm{mg}$. The androstenedione was therefore considered radiochemically pure at this point.

$17 \beta$-Hydroxyprogesterone: The pool of $17 \alpha$-hydroxyprogesterone contained $1.61 \mathrm{mg}(239 \mathrm{~m} \mu)$ and 22,100 cpm; $10 \mathrm{mg}$ of $17 \alpha$-hydroxyprogesterone carrier was added and the whole subjected to a 99-transfer ccd in methanol: water $(70: 30) /$ chloroform: carbon tetrachloride $(10: 90)$. The peak in radioactivity coincided with the peak in the $17 \alpha$-hydroxyprogesterone as measured by ultraviolet absorption $(\mathrm{K}=0.49)$. The mean specific activity around the peak was $1,900 \pm 167 \mathrm{cpm}$ per $\mathrm{mg}$. The material from this peak was crystallized twice from aqueous ethanol to give crystals having specific activities of 1,670 and $1,740 \mathrm{cpm}$ per $\mathrm{mg}$ (calculated $1,900 \mathrm{cpm}$ per $\mathrm{mg}$ ). Crystallization from benzene: cyclohexane gave crystals, $1,740 \mathrm{cpm}$ per $\mathrm{mg}$ and a mother liquor residue, $1,750 \mathrm{cpm}$ per $\mathrm{mg}$. The $17 \alpha$-hydroxyprogesterone was considered radiochemically pure at this point.

Dehydroepiandrosterone: The recovered dehydroepiandrosterone was analyzed by the Zimmermann reaction (25) and contained $2.11 \mathrm{mg}$ and $3,800 \mathrm{cpm} ; 10 \mathrm{mg}$ of unlabeled dehydroepiandrosterone was added and the whole was subjected to a 99-transfer ccd in methanol: water $(80: 20) /$ carbon tetrachloride. A single peak (Zimmermann) of carrier was found $(K=1.25)$; there were two peaks in radioactivity-one $(K=8.00)$ contained $745 \mathrm{cpm}$; the larger peak corresponded to the peak in dehydroepiandrosterone $(K=1.25)$, but contained other labeled material since it failed to fit the theoretical distribution curve. This peak contained about $2,100 \mathrm{cpm}$. The contents of the tubes containing the dehydroepiandrosterone were combined and crystallized five times from aqueous ethanol giving crystals containing $87,102,86,84$, and $90 \mathrm{cpm}$ per $\mathrm{mg}$ and a final mother liquor residue having $110 \mathrm{cpm}$ per mg. Crystallization from acetone: hexane yielded crystals containing $85 \mathrm{cpm}$ per mg and a mother liquor residue of $75 \mathrm{cpm}$ per mg. The last crystals were subjected to a 24-transfer ccd in ethyl acetate: cyclohexane $(30: 70) /$ ethanol: water $(55: 45)$. The peak in radioactivity coincided with the peak in dehydroepiandrosterone (Zimmermann reaction, $\mathrm{K}=1.04$ ). Constant specific activity, $80 \pm 12 \mathrm{cpm}$ per $\mathrm{mg}$ in the region of the peak, indicated radiochemical purity. The dehydroepiandrosterone was then considered radiochemically pure.

Testosterone: The testosterone as isolated from the incubation mixture was impure as indicated by its ultraviolet absorption spectrum. It was, therefore, rechromatographed in ligroin: toluene $(67: 33) /$ methanol: water $(70: 30)$. It then had a satisfactory spectrum indicating a recovery of $1.12 \mathrm{mg}$ and contained $4,800 \mathrm{cpm}$; $10 \mathrm{mg}$ of carrier testosterone was added and the whole subjected to a 99-transfer ccd in methanol: water (80: 20)/chloroform: carbon tetrachloride $(10: 90)$. A single peak in material absorbing at $240 \mathrm{~m} \mu$ coincided with the single peak in radioactivity $(\mathrm{K}=1.19)$; however, the experimental points for radioactivity did not agree well with the theoretical curve, thus indicating the presence of a radioactive impurity. The peak contained $9.73 \mathrm{mg}$ and $3,380 \mathrm{cpm}$. The contents of the tubes containing the testosterone were crystallized five times from aqueous ethanol. The specific activities of the crystals were 306 , $312,255,196$, and $206 \mathrm{cpm}$ per $\mathrm{mg}$, and that of the residue in the final mother liquor, $276 \mathrm{cpm}$ per $\mathrm{mg}$. Crystallization from acetone: hexane yielded crystals containing $223 \mathrm{cpm}$ per $\mathrm{mg}$ and a residue in the mother liquor of $210 \mathrm{cpm}$ per $\mathrm{mg}$. In view of these results and the relatively high level of activity associated with the closely related androstenedione, the testosterone was considered labeled. 


\section{DISCUSSION}

\section{Methods for radiochemical purity}

In the demonstration of radiochemical purity of the isolated steroid carriers, it has been our experience that radioactive contamination is relatively unlikely when the radioactive starting material is a steroid closely related to the products; thus, in Experiments A and B, achievement of radiochemical purity presented no serious difficulties. This was not true when the radioactive starting material was a substance far removed (in the biosynthetic sense) from the products under study, as in Experiments $C$ and D in which cholesterol- $\mathrm{C}^{14}$ and acetate- $\mathrm{C}^{14}$ were incubated. In one, only a small percentage of the radioactivity was ultimately associated with the steroid carriers, while in the other (Experiment C), demonstration of radiochemical purity was not achieved; the purification problem in these latter cases appears to have been compounded by the large variety and unknown nature of the radioactive impurities, particularly in the cholesterol- $\mathrm{C}^{14}$ study.

We have found that after separation and isolation of the carrier steroids in chemically pure state, several purification measures may be used to demonstrate radiochemical purity, the main criterion being constancy of specific activity of the steroid at each step through a series of physical and chemical manipulations. The greater the number of such manipulations without significant change in specific activity, the greater the likelihood that the compound is radiochemically pure. Conversely, decreases in specific activity through these manipulations signify contamination of the carrier by some trace impurity.

Among the various manipulations currently employed for purification, countercurrent distributions have proven particularly useful, since nonhomogeneity can be readily detected when the radioactive compound and the steroid carrier have only slightly different partition coefficients in the system employed (45). Formation of suitable derivatives is also of value, since two compounds (steroid carrier and radioactive compound) which have very similar physical properties may form derivatives having less similar properties. In this regard, the steroid carrier derivative selected should be one which is based upon the most characteristic chemical feature of the carrier and which effects the maximum alteration in its physical properties. Crystallization (of steroid carriers and derivatives), however, has been the manipulation most widely used as the criterion for radiochemical purity, since a trace contaminant is likely to be completely soluble in the solvent used to crystallize the larger amount of carrier. Unfortunately, with steroids, this ideal situation is often complicated by adsorption of impurities on crystals and even mixed crystal formation (this phenomenon may explain the tenacity of the contaminants encountered in Experiment C). Purification to constant specific activity in a particular solvent may be considered to have been achieved when specific activity remains constant through several recrystallizations. When only small quantities of carrier are available, however, the above is not always possible; in such cases we have found it necessary to carry out specific activity measurements on both crystals and mother liquors from each crystallization in order to determine if constant specific activity has been achieved in that particular solvent.

These criteria served to provide the values given in Table IV for Experiments A, B and D; the same criteria applied to the steroids in the cholesterol- $\mathrm{C}^{14}$ study (Experiment $\mathrm{C}$ ) indicated that the associated radioactivity was largely due to unknown impurities. To be noted is the value of the isolation of several carriers devoid of radioactivity; such negative results lend considerable confidence to the positive values obtained in the same study.

\section{Biochemical considerations}

The elevated level of the urinary 17 -ketosteroids seen in the patient preoperatively is consistent with the classical clinical features of interstitial cell tumors of the testis in childhood (1-21). Analysis of the individual 17-ketosteroids revealed androsterone and etiocholanolone (Table II) to be present in the largest amounts. Metabolic studies in humans (50) show that the principal precursors of these two urinary $\mathrm{C}_{19} \mathrm{O}_{2}$ steroids are androstenedione, testosterone and dehydroepiandrosterone, and that the two metabolites are usually excreted in approximately equal amounts, as they are in our patient (Table II). The elevated levels of the 11-oxygenated 17-ketosteroids in the 
urine are most impressive since the occurrence of an oxygen substituent at carbon-11 of a steroid of mammalian origin has long been considered indicative of that steroid's adrenal cortical origin. The high concentration of 11 -keto- and $11 \beta$-hydroxyandrosterone (1.8 $\mathrm{mg}$ per 24 hours) indicates that at least one of the likely precursors (51) - 11 $\beta$-hydroxyandrostenedione, adrenosterone or $11 \beta$-hydroxytestosterone-was formed by the tumor; these three latter compounds have been isolated from adrenal tissue either as constituents or as metabolic products (52-55). The urinary 17 -ketosteroid pattern thus suggests that the principal $\mathrm{C}_{19} \mathrm{O}_{2}$ androgen elaborated was testosterone or androstenedione (or perhaps dehydroepiandrosterone), and that one of the more weakly androgenic $\mathrm{C}_{10} \mathrm{O}_{3}$ compounds-11 $\beta$-hydroxyandrostenedione, $11 \beta$-hydroxytestosterone, or adrenosterone $(56,57)$-was formed in lesser amounts. The preoperative levels of urinary pregnanetriol suggest also the likelihood of the formation by the tumor of $17 \alpha$-hydroxyprogesterone (50).

The results of the acetate incubation study, given in Table IV, indicate that androstenedione and testosterone are indeed the major steroids elaborated by the tissue under the conditions of incubation and, no doubt, account for the virilizing properties of this tumor. The accumulation of $\mathrm{C}^{14}$ in both these compounds amounts to 0.07 per cent of the added acetate. 11- $\beta$-Hydroxyandrostenedione and its companion adrenosterone $(11 \beta$ hydroxytestosterone was not sought) accumulated 0.04 per cent. Thus, in the acetate experiment, the ratio of $\mathrm{C}_{19} \mathrm{O}_{2}$ to $\mathrm{C}_{19} \mathrm{O}_{3}$ steroids is in excellent agreement with the quantitative relationship of these two classes of steroids found in the urine.

In the study with acetate- $\mathrm{C}^{14}$, little or no radioactivity was associated with progesterone while a significant amount accumulated in $17 \alpha$-hydroxyprogesterone. Perfused stallion testes have been shown to incorporate acetate- $\mathrm{C}^{14}$ into both progesterone and 17 $\alpha$-hydroxyprogesterone (58), and a human embryonal testicular tumor, under tissue-slice conditions, elaborated progesterone (31) in addition to androstenedione and testosterone. Our incubation studies suggest that while these two $\mathrm{C}_{21}$-compounds appear to act in this tumor as intermediates (see below) in the biosynthetic pathway to the androgens (Experiment B), both may well have been secreted by this tumor in vivo, their production being reflected by the elevated urinary titers of pregnanetriol and neutral acylable lipids (Table I), although the latter may be made up of $\mathrm{C}_{19}$-diol compounds. The relatively minor amount of dehydroepiandrosterone obtained in the incubation with acetate- $\mathrm{C}^{14}$ (Table IV), suggests that this substance was transformed rapidly by the tissue and therefore accumulated little or no radioactivity in the in vivo study.

The incubation of the tumor tissue with cholesterol- $\mathrm{C}^{14}$ was undertaken with the notion that an efficient utilization and transformation of labeled cholesterol into steroid hormone products would occur. This premise has proved to be false. This does not necessarily mean that cholesterol is not an intermediate in the synthesis of steroid hormones in this tumor. Although the tissue was capable of active steroid synthesis as seen in the other experiments, no significant amount of cholesterol- $\mathrm{C}^{14}$ was transformed into recognizable $\mathrm{C}_{19}$ or $\mathrm{C}_{21}$ steroid products. Dilution of the radioactive cholesterol by the tissue and medium cholesterol, or its failure to penetrate cell membranes could explain the negative results. However, the cholesterol- $\mathrm{C}^{14}$ did undergo some chemical transformations to more polar material, as indicated by the large amounts of radioactivity found in the polar fractions accompanying the steroid carriers. This unidentified material, which may have been a biochemical transformation product or an artifact, accompanied the carrier steroids through several purifications, including the formation of derivatives.

The results of the incubation of testosterone- $\mathrm{C}^{14}$ (Experiment A) are clear-cut. The major transformation product of testosterone was androstenedione, known to be a normal secretory product of human (59) and dog testicular tissue (60). The presence in this tumor of the enzyme, $11 \beta$ hydroxylase (61), was demonstrated by the isolation of radioactive $11 \beta$-hydroxyandrostenedione and $11 \beta$-hydroxytestosterone (54). The significance of this reaction in testicular tumor tissue is discussed below. The formation of radioactive adrenosterone in minor amounts points to the presence of the widely occurring 11-hydroxydehydrogenase (62) in this tumor tissue or possibly in the plasma used in the incubating medium. It 
should be noted that no radioactive products other than the four described were found in this experiment and that the $11 \beta$-hydroxylase activity of the tissue is demonstrated by the fact that 7.6 per cent of the added testosterone was converted to 11-oxygenated steroids.

The isolation of radioactive $17 \alpha$-hydroxyprogesterone, testosterone and androstenedione from the progesterone- $\mathrm{C}^{14}$ incubation experiment (Table IV, Experiment B) serves to indicate the pathway for the formation of androgens by this tumor tissue. Slaunwhite and Samuels (63) described the transformation of progesterone into androstenedione and testosterone by rat testicular tissue and postulated that $17 \alpha$-hydroxyprogesterone is an intermediate. These transformations have been confirmed by the present study, by Solomon, Vande Wiele and Lieberman (64) in bovine ovarian tissue, and by Lynn and Brown (65) and one of the authors in normal rat testis tissue, which has also been shown to transform $17 \alpha$-hydroxyprogesterone- $\mathrm{C}^{14}$ into radioactive androstenedione and testosterone (66). The presence of $11 \beta$-hydroxyandrostenedione among the transformation products of progesterone is consistent with the results of the testosterone incubation. The absence of $11 \beta$-hydroxyprogesterone and 11-ketoprogesterone from the products derived from progesterone is interesting in view of the isolation of 11-oxygenated $\mathrm{C}_{19}$ compounds in this and other incubations. This may suggest that the tumor $11 \beta$-hydroxylase exhibits a substrate preference (61). A final point of interest is the apparent failure of this tumor tissue to convert progesterone to either of the two substances, $20 \alpha$ - or $20 \beta$-hydroxy-4pregnen-3-one. They have been shown to be produced from progesterone by human (66) and bovine (67) ovarian tissue in vitro, and by the eviscerated rat in vivo (68), and normally accompany progesterone in the blood of pregnant women and in human follicles, corpora lutea and possibly in placental blood (35).

\section{Clinical considerations}

There are 22 previously reported cases of socalled interstitial cell tumors of the testis occurring in childhood and producing isosexual precocity (1-21). In the present case the demonstration in the tumor of certain biochemical activities
( $11 \beta$-hydroxylase activity, formation of $11 \beta$-hydroxyandrostenedione and related compounds), which more closely resemble those of adrenal cortical than of testicular tissue, requires reappraisal of the status of the interstitial cell tumor of the testis.

As with the previous 22 cases, our patient displayed clinical abnormalities attributable to the overproduction of androgens: precocious statural and isosexual growth, advanced skeletal maturation, excessive muscular development, facial acne and hirsutism. Precocity began between the ages of three and six years in almost all reported cases, including the present one, and the tumor was unilateral and benign in all but one case. Correlated with this, in our case and nine previous cases so studied, urinary 17-ketosteroids were elevated for the age, ranging from 2.9 to $64 \mathrm{mg}$ per 24 hours. Gynecomastia was observed in three previous cases but not in the present one, where urinary estrogen was in the normal range and none was formed by the tumor tissue in vitro (Experiment D). A clue to the gynecomastia in the three cases may be in the recent demonstration of the conversion of androgen to estrogen by human endocrine (69) and nonendocrine tissues (70) and the observation of gynecomastia following androgen administration (71).

The origins of these tumors are not clear. First, there are no precise morphologic criteria for differentiating adrenal cortical cells from interstitial cells of Leydig $(11,72)$, and secondly, adrenal cortical rests do occur in the testes. This is not surprising since the adrenal cortex arises embryologically in the dorsal mesenteric root in close proximity to the urogenital ridge containing the gonads (73). In this way it is conceivable that these tumors can resemble adrenal cortical tissue both morphologically and biochemically. On the other hand, massive replacement of testicular tissue by aberrant adrenal cortical cells in a patient with congenital virilizing adrenal cortical hyperplasia has been reported by Wilkins and co-workers (74). Subsequently, this has been confirmed, and in 1954, Hedinger reported a similar patient in whom cortisone administration induced marked regression of testicular size (75). Staubitz and co-workers in 1953 reported a patient with bilateral "interstitial cell tumors" with precocity beginning at three years of age, but in whom urinary 
17-ketosteroids were $73.9 \mathrm{mg}$ per 24 hours before bilateral orchiectomy and still elevated at 69.6 mg per 24 hours three months postoperatively (76), suggesting that this was an instance of adrenogenitalism with bilateral adrenal cortical rests in the testes; for this reason it has not been included in our list of previously reported cases of interstitial cell tumors of the testis. Because of insufficient data for diagnosis, another case with bilateral testicular tumors reported by Garvey and Daniel has been excluded from our series (77). We have accepted the case reported by Rezek and Hardin (19) with bilateral testicular tumors, primarily on the basis of a decrease in 17 -ketosteroids from 91 ( 60 per cent " $\beta$-ketosteroids") to 2.1 (no " $\beta$-ketosteroids") $\mathrm{mg}$ per 24 hours 16 months postoperatively. However, the preoperative level of $3 \beta$-hydroxy-17-ketosteroids in the urine is suggestive evidence for tumor formation from adrenal-cortical cell rests. Sandblom's patient has been included perhaps incorrectly in our series, since at four years of age and one year postoperatively the urinary 17-ketosteroids varied between 10 and $20 \mathrm{mg}$ per 24 hours as compared to $64 \mathrm{mg}$ per 24 hours before surgery (8). There thus appears, probably for want of completeness in their work-up, an obscure picture of the "testicular" origins of these tumors; in some instances they possess the distinct character of adrenal cortical rests, while in those included in our series, they show no such morphological properties.

There is one histological finding that has long been considered specific for Leydig cells, namely the presence of crystalloids of Reinke (78). These also occur in the ovarian hilus cells but have never been described in adrenal cortical tissue. Recently Sternberg, Segaloff and Gaskill have reaffirmed that these crystalloids are indeed "specific identification tags, distinguishing hilus and Leydig cells from morphologically similar cells such as lutein and adrenal cortical cells" (79). Although absent in each of the previously reported cases of prepubertal interstitial cell tumors, crystalloids of Reinke were clearly demonstrated in the tumor of our patient. Thus, on the one hand this tumor had this morphologically identifying stigma of testicular origin, while on the other hand, its biochemical activity suggested certain adrenal cortical properties. Here the enigma must rest, but we are forced to re-open the question as to tissue specificity of both the crystalloids of Reinke and the capacity to elaborate $11 \beta$-hydroxysteroids. Perhaps it should be re-emphasized that while $11 \beta$-hydroxylase activity has never been previously observed in normal testicular tissue, no distinct search has been made until very recently; it was not found in normal stallion testis tissue (58) and could not be demonstrated in an arrhenoblastoma (66). The apparent absence of $11 \beta$-hydroxylase from normal testicular and ovarian tissues may however reflect a failure of analytical techniques to detect extremely low concentrations of enzymatic activity. The process of tumor formation could bring about an increase in concentration of an enzyme normally considered absent from the tissue, and seemingly could cause the tumor to "acquire" an enzyme not usually associated with the parent tissue. The recent report of the enzyme 21-hydroxylase (likewise generally associated with adrenal cortical tissue) in an induced tumor of testicular interstitial cell origin in the mouse (80) suggests such a possibility.

Our patient's postoperative course during two years of observation has been of considerable interest. His excessive libido gradually subsided and social adjustment improved, but there was no regression of the physical manifestations of precocity; indeed, he continued to mature. Growth continued at approximately the same rate as preoperatively, but the bone age advanced only one to two years. The remaining left testis, small preoperatively, increased to late-adolescent size with normal consistency. Urinary gonadotropins, which were absent preoperatively, reached the normal adult range of 7 rat uterine units. The urinary 17-ketosteroid levels fell precipitously after operation to approximately $1.0 \mathrm{mg}$ per 24 hours, but during the last year of observation have varied between 3.0 and $7.4 \mathrm{mg}$ per 24 hours. The above data suggest that postoperatively the patient entered true puberty with its attendant gonadotropin production, growth spurt and maturation of the remaining testis. This simulates the sexual maturation which has been observed during cortisone therapy of patients with the adrenogentital syndrome in whom somatic maturation, reflected by a bone age of 11 to 12 years, had taken place prior to treatment (81). It would appear that, irrespective of chronological age, some re- 
lationship exists between the level of somatic and skeletal development and the initiation of the hypothalamic-pituitary discharge which leads to elaboration of gonadotropin. The normal adolescent values of urinary gonadotropins, 17-ketosteroids and pregnanetriol postoperatively in our patient are evidence against either development of a new tumor in the remaining testis or of adrenal hyperplasia as a basis for the subsequent continued somatic and sexual development.

Inadequate data are available on the postoperative course of the 22 previously reported cases. In general, the literature reports little or no regression of the precocious physical characteristics. In two patients with preoperative heights of 152 $\mathrm{cm}$ there was no further growth postoperatively, probably reflecting closure of the epiphyses prior to surgical excision of the tumors. However, in five patients whose preoperative height was less than $127 \mathrm{~cm}$ and whose bone age was 12 years or less, a deceleration of growth rate and genital development was specifically noted. One other patient, with a preoperative height of $120.7 \mathrm{~cm}$ and a bone age of 10 years, grew $20 \mathrm{~cm}$ during the first 17 months after operation, and the remaining testis appeared to be enlarging. While the latter patient's course is suggestively similar to that of our own case, no testicular biopsy nor gonadotropin assays were reported. In three patients with gynecomastia, breast enlargement disappeared in two and persisted in one.

This protracted study has served to demonstrate that the virilizing properties of this tumor may be ascribed to two principal androgenic steroids, testosterone and 4-androstenedione, whose formation in the tumor is consistent with the mechanism of androgen biosynthesis recently postulated for normal testicular tissue (63) (Figure 7$)$. The demonstration of the presence of the enzyme $11 \beta$-hydroxylase points to certain hitherto unsuspected endocrine and embryological considerations of this tumor. The implications of these observations as to the nature of the hormone-secreting cells of this tissue must await the extension of these studies to similar virilizing tumors of the testis.

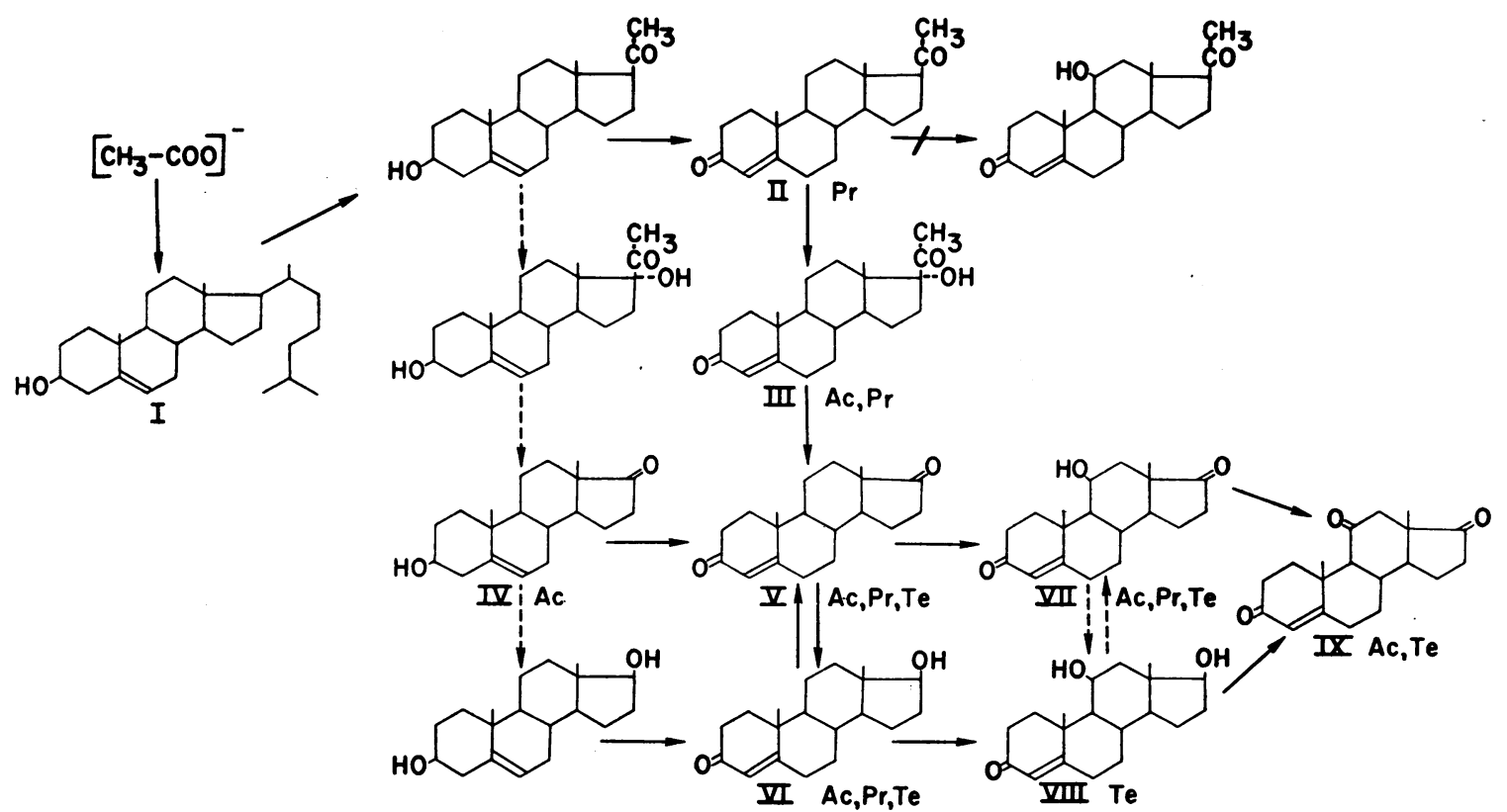

Fig. 7. Probable pathway of steroid biosynthesis in the testicular tumor. Broken arrows indicate presumed transformations; $\mathrm{Te}=$ produced from testosterone-4- $\mathrm{C}^{14}$ in Experiment $\mathrm{A}$; $\mathrm{Pr}=$ produced from progesterone-4- $\mathrm{C}^{\mathbf{1 4}}$ in Experiment $\mathrm{B}$; $\mathrm{Ac}=$ produced from acetate-1- $\mathrm{C}^{\mathbf{1 4}}$ in Experiment $\mathrm{D}$. $\mathrm{I}=$ cholesterol; II $=$ progesterone; III $=17 \alpha$-hydroxyprogesterone $;$ IV $=$ dehydroepiandrosterone $; \mathrm{V}=4$-androstene-3,17-dione ; VI $=$ testosterone; VII = 11 $\beta$-hydroxy-4-androstene-3,17-dione; VIII = 11 $\beta, 17 \beta$-dihydroxy-4-androstene-3-one $(11 \beta$-hydroxytestosterone); IX = adrenosterone. 


\section{SUMMARY}

An interstitial cell tumor in the testis was removed from a highly virilized boy. The preoperative levels of urinary $11 \beta$-hydroxyandrosterone, $11 \beta$-hydroxyetiocholanolone, 11-ketoandrosterone, androsterone, etiocholanolone and pregnanetriol were abnormally high and fell promptly following surgery. After incubation of tumor slices with acetate-1-C $\mathrm{C}^{\mathbf{1 4}}$, the following radioactive steroids were found by carrier dilution: testosterone, 4-androstene-3,17-dione, (in small amount) dehydroepiandrosterone, $17 \alpha$-hydroxyprogesterone, adrenosterone and $11 \beta$-hydroxyandrostenedione; estrone, estradiol-17 $\beta$, estriol, progesterone and $11 \beta$ - and $6 \beta$-hydroxyprogesterone were isolated devoid of radioactivity. Incubation with progesterone-4-C ${ }^{14}$ yielded radioactive $17 \alpha$-hydroxyprogesterone, androstenedione, testosterone and $11 \beta$ hydroxyandrostenedione. Incubation with testosterone-4- $\mathrm{C}^{14}$ yielded radioactive androstenedione, $11 \beta$-hydroxytestosterone, $11 \beta$-hydroxyandrostenedione and adrenosterone. Cholesterol-4- $\mathrm{C}^{14}$ failed to give rise to significant amounts of radioactive steroid products.

A critique of methods for the study of radiochemical purity of steroids is presented.

The morphological, biochemical and clinical aspects of this twenty-third reported case of virilizing interstitial cell tumor of the testis are discussed.

\section{REFERENCES}

1. Sacchi, E. Di un caso di gigantismo infantile (Pedomacrosomia) con tumore del testicolo. Riv. sper. Freniat. 1895, 21, 149.

2. Rowlands, R. P., and Nicholson, G. W. Growth of the left testicle with precocious sexual and bodily development (macro-genito-somia). Guy's Hosp. Rep. 1929, 79, 401.

3. Stewart, C. A., Bell, E. T., and Roehlke, A. B. An interstitial-cell tumor of the testis with hypergenitalism in a child of five years. Amer. J. Cancer 1936, 26, 144.

4. Somerford, A. E. A case of interstitial cell tumor of the testis in a boy of eleven years. Brit. J. Urol. 1941, 13, 13.

5. Huffman, L. F. Interstitial cell tumor of the testicle : Report of a case. J. Urol. 1941, 45, 692.

6. Werner, A. A., Spector, H. I., Vitt, A. E., Ross, W. L., and Anderson, W. A. D. Pubertas precox in a six-year-old boy produced by a tumor of the testis, probably of interstitial cell origin. J. clin. Endocr. 1942, 2, 527.
7. Urban, N. Rückbildungserscheinungen bei Pubertas praecox. Mschr. Kinderheilk. 1942, 90, 11.

8. Sandblom, P. Precocious sexual development produced by an interstitial cell tumor of the testis. Acta endocr. (Kbh.) 1948, 1, 107.

9. Fraser, K. B. Interstitial cell tumours of the testis. The male sex hormone. Aust. N. Z. J. Surg. 1949, $19,48$.

10. Melicow, M. M., Robinson, I. N., Ivers, W., and Rainsford, L. K. Interstitial cell tumors of the testis. J. Urol. 1949, 62, 672.

11. James, D. C., and Shupe, R. D. Interstitial cell tumor of the testicle with report of a case. J. Urol. 1950, $63,718$.

12. Newns, G. H. Precocious sexual development due to an interstitial-cell tumour of the testis. Brit. J. Surg. 1952, 39, 379.

13. Cook, C. D., Gross, R. E., Landing, B. H., and Zygmuntowicz, A. S. Interstitial cell tumor of the testis. Study of a 5-year-old boy with pseudoprecocious puberty. J. clin. Endocr. 1952, 12, 725.

14. Anagnostou, J., and Frangopoulos, G. J. Pubertas praecox caused by interstitial-cell tumour of testicle. Brit. med. J. 1953, 1, 861.

15. Demetriadis, T., et al. Arch. med Sci. (Athens) 1948, quoted by Aragnostou, J., and Frangopoulos, B. J. (14).

16. Thamdrup, E. Macrogenitosomia caused by interstitial cell tumor of the testis. A case in a $71 / 2$ year-old boy. Acta Paediat. 1953, 42, 369.

17. Hertz, R., Cohen, M. I., Lewis, L. G., and Firminger, H. I. Sexual precocity in a 5-year-old boy with interstitial-cell tumor of the testis. J. clin. Endocr. 1953, 13, 1248.

18. Pomer, F. A., Stiles, R. E., and Graham, J. H. Interstitial-cell tumors of the testis in children. New Engl. J. Med. 1954, 250, 233.

19. Rezak, P., and Hardin, H. C., Jr. Bilateral interstitial cell tumor of the testicle: Report of one case observed fourteen years. J. Urol. 1955, 74, 628.

20. Jolly, H. Sexual Precocity. Springfield, Charles C Thomas, 1955, p. 62.

21. Jungck, E. C., Thrash, A. M., Ohlmacher, A. P., Knight, A. M., Jr., and Dryenforth, L. Y. Sexual precocity due to interstitial-cell tumor of the testis: Report of two cases. J. clin. Endocr. 1957, 17, 291.

22. Hooker, C. W. The postnatal history and function of the interstitial cells of the testis of the bull. Amer. J. Anat. 1944, 74, 1.

23. Pollock, W. F. Histochemical studies on the interstitial cells of the testis. Anat. Rec. 1942, 84, 23.

24. Venning, E. H., Hoffman, M. M., and Browne, J. S. L. Isolation of androsterone sulfate. J. biol. Chem. 1942, 146, 369.

25. Nathanson, I. T., and Wilson, H. Factors affecting colorimetric urinary 17-ketosteroid determinations. Endocrinology 1943, 33, 189. 
26. Baggett, B., Engel, L. L., and Fielding, L. L. The estimation of hydroxysteroids. J. biol. Chem. $1955,213,87$.

27. Engel, L. L., Slaunwhite, W. R., Jr., Carter, P., and Nathanson, I. T. The separation of natural estrogens by counter-current distribution. J. biol. Chem. 1950, 185, 255.

28. Silber, R. H., and Porter, C. C. The determination of 17,21-dihydroxy-20-ketosteroids in urine and plasma. J. biol. Chem. 1954, 210, 923.

29. Bush, I. E. Methods of paper chromatography of steroids applicable to the study of steroids in mammalian blood and tissues. Biochem. J. 1952, 50, 370.

30. Engel, L. L. Unpublished data.

31. Wotiz, H. H., Davis, J. W., and Lemon, H. M. Steroid biosynthesis by surviving testicular tumor tissue. J. biol. Chem. 1955, 216, 677.

32. Anliker, R., Perelman, M., Rohr, O., and Ruzicka, L. Untersuchungen über Organextrakte 27. Mitteilung. Uber die Konzentration des Testosterons in menschlichen Testes. Helv. chim. Acta 1957, 40, 1520.

33. Anliker, R., Rohr, O., and Ruzicka, L. Untersuchungen über Organextrakte, 26. Mitteilung. Über den Nachweis von androgenen Hormonen in einem virilisierenden Ovarialtumor. Justus Liebigs Ann. Chem. 1957, 603, 109.

34. Zander, J. Steroids in the human ovary. J. biol. Chem. 1958, 232, 117.

35. Zander, J., Forbes, T. R., von Münstermann, A. M., and Neher, R. $\Delta^{4}$-3-ketopregnene-20 $\alpha$-ol and $\Delta^{4-3-}$ ketopregnene- $20 \beta$-ol, two naturally occurring metabolites of progesterone. Isolation, identification, biologic activity and concentration in human tissues. J. clin. Endocr. 1958, 18, 337.

36. Neher, R., and Wettstein, A. Physicochemical detection and measurement of aldosterone in body fluids and tissues. Acta endocr. (Kbh.) 1955, 18, 386.

37. Burton, R. B., Zaffaroni, A., and Keutmann, E. H. Paper chromatography of steroids. II. Corticosteroids and related compounds. J. biol. Chem. 1951, 188, 763.

38. Savard, K. Paper partition chromatography of $\mathrm{C}_{10^{-}}$ and $\mathrm{C}_{21}$-ketosteroids. J. biol. Chem. 1953, 202, 457.

39. Kochakian, C. D., and Stidworthy, G. Paper chromatography of $\mathrm{C}_{19}$ steroids. J. biol. Chem. 1952, 199, 607.

40. Richardson, E. M., Touchstone, J. C., and Dohan, F. C. Urinary alpha-ketolic steroid metabolites of cortical hormones administered to subjects with adrenal cortical insufficiency. J. clin. Invest. 1955 34, 285.

41. Rosenkrantz, H. An antimony trichloride reagent suitable for the detection and estimation of nonketonic steroids. Arch. Biochem 1953, 44, 1.
42. Marinelli, L. D., and Hill, R. F. Radioautography: Some physical and radiobiological aspects of the technique as applied to thin specimens. Amer. J. Roentgenol. 1948, 59, 396.

43. Zaffaroni, A., and Burton, A. B. Identification of corticosteroids of beef adrenal extract by paper chromatography. J. biol. Chem. 1951, 193, 749.

44. Folch, J., Lees, M., and Sloane Stanley, G. H. A simple method for the isolation and purification of total lipides from animal tissues. J. biol. Chem. 1957, 226, 497.

45. Baggett, B., and Engel, L. L. The use of countercurrent distribution for the study of radiochemical purity. J. biol. Chem. 1957, 229, 443.

46. Reichstein, T., and von Euw, J. Über Bestandteile der Nebenniererinde. 18. Die Verseifung von estern reduzierender Ketole mit Schwachen Alkalien. Helv. chim. Acta 1938, 21, 1181.

47. Weisiger, J. R. Countercurrent distribution in Organic Analysis, John Mitchell, Jr., Ed. New York, Interscience Publishers, 1954, vol. II, p. 277

48. Balant, C. P., and Ehrenstein, M. Investigations on steroids. XX. $6 \beta$ - and $6 \alpha$-acetoxy- and hydroxyderivatives of progesterone and androstenedione. J. org. Chem. 1952, 17, 1587.

49. Frame, E. G. A micro method for the separation of 17-ketosteroids into alpha and beta fractions. Endocrinology 1944, 34, 175.

50. Dorfman, R. I. Neutral steroid hormone metabolites. Recent Progr. Hormone Res. 1954, 9, 5.

51. Savard, K., Burstein, S., Rosenkrantz, H., and Dorfman, R. I. The metabolism of adrenosterone in vivo. J. biol. Chem. 1953, 202, 717.

52. Reichstein, T., and Shoppee, C. W. The hormones of the adrenal cortex. Vitam. and Horm. 1943, 1, 345 .

53. Wettstein, A. Advances in the field of adrenal cortical hormones. Experientia (Basel) 1954, 10, 397.

54. Axelrod, L. R., and Arroyave, G. Biosynthesis and characterization of 11 $\beta$-hydroxytestosterone. J. Amer. clem. Soc. 1953, 75, 5729.

55. Bloch, E., Dorfman, R. I., and Pincus, G. Presence of 17 -ketosteroids in adrenal perfusates. Proc. Soc. exp. Biol. (N. Y.) 1954, 85, 106.

56. Dorfman, R. I., and Shipley, R. A. Androgens: Biochemistry, Physiology, and Clinical Significance. New York, John Wiley and Sons, Inc., 1956.

57. Dorfman, R. I. Unpublished data.

58. Savard, K., and Goldzieher, J. W. Biosynthesis of steroids in stallion testis tissue. Endocrinology 1960, 66. In press.

59. Savard, K., Dorfman, R. I., and Poutasse, E. Biogenesis of androgens in the human testis (abstract). J. clin. Endocr. 1952, 12, 935.

60. West, C. D., Hollander, V. P., Kritchevsky, T. $\mathrm{H}$., and Dobriner, $\mathrm{K}$. The isolation and identification of testosterone, $\Delta^{4}$-androstenedione-3,17 
and 7-ketocholesterol from spermatic vein blood (abstract). J. clin. Endocr. 1952, 12, 915.

61. Hayano, M., and Dorfman, R. I. The enzymatic C-11 $\beta$-hydroxylation of steroids. J. biol. Chem. 1953, 201, 175.

62. Hubener, H. J., Fukushima, D. K., and Gallagher, T. F. Substrate specificity of enzymes reducing the 11 - and 20-keto groups of steroids. J. biol. Chem. 1956, 220, 499.

63. Slaunwhite, W. R., Jr., and Samuels, L. T. Progesterone as a precursor of testicular androgens. J. biol. Chem. 1956, 220, 341.

64. Solomon, S., Vande Wiele, R., and Lieberman, S. The in vitro synthesis of $17 \alpha$-hydroxyprogesterone and $\Delta^{4}$-androstene-3,17-dione from progesterone by bovine ovarian tissue. J. Amer. chem. Soc. 1956, 78, 5453.

65. Lynn, W. S., and Brown, R. Mechanism of in vitro steroid oxidation. Biochim. biophys. Acta 1956, 21, 403.

66. Savard, K. Unpublished data.

67. Hayano, M., Lindberg, M. C., Wiener, M., Rosenkrantz, H., and Dorfman, R. I. Steroid transformations by corpus luteum tissue. Endocrinology 1954, 55, 326.

68. Wiest, W. G. The metabolism of progesterone to $\Delta^{4}$-pregnen-20 $\alpha$-ol-3-one in eviscerated female rats. J. biol. Chem. 1956, 221, 461.

69. Baggett, B., Engel, L. L., Savard, K., and Dorfman, R. I. The conversion of testosterone-3-C $C^{14}$ to $\mathrm{C}^{14}-$ estradiol-17 $\beta$ by human ovarian tissue. J. biol. Chem. 1956, 221, 931.

70. West, C. D., Damast, B. L., Sarro, S. D., and Pearson, $\mathrm{O}$. $\mathrm{H}$. Conversion of testosterone to estrogens in castrated, adrenalectomized females. J. biol. Chem. 1956, 218, 409.

71. McCullagh, E. P., and Rossmiller, H. R. Methyl testosterone; androgenic effects and the production of gynecomastia and oligospermia. J. clin. Endocr. 1941, 1, 496.

72. Cohen, $H$. Hyperplasia of the adrenal cortex associated with bilateral testicular tumors. Amer. J. Path. 1946, 22, 157.

73. Arey, L. B. Developmental Anatomy, 6th ed. Philadelphia, W. B. Saunders Co., 1954.

74. Wilkins, L., Fleischmann, W., and Howard, J. E. Macro-genitosomia praecox associated with hyperplasia of the androgenic tissue of the adrenal and death from adrenocortical insufficiency; case report. Endocrinology 1940, 26, 385.

75. Hedinger, C. Beidseitige Hodentumoren und kongenitales adrenogenitales Syndrom; Leydig-Zellen oder Nebennierenrindengewebe? Schweiz. Z. allg. Path. 1954, 17, 743.

76. Staubitz, W. J., Oberkircher, O. J., and Blick, M. S. Precocious puberty in a case of bilateral interstitial cell tumor of the testes. J. Urol. 1953, 69, 562.

77. Garvey, F. K., and Daniel, T. B. Bilateral interstitial cell tumor of the testicle. J. Urol. 1951, 66, 713.

78. Reinke, F. Beiträge zur Histologie des Menschen. I. Ueber Krystalloidbildurgen in den interstitiellen Zellen des menschlichen Hoders. Arch. mikr. Anat. 1896, 47, 34.

79. Sternberg, W. H., Segaloff, A., and Gaskill, C. J. Influence of chorionic gonadotropin on human ovarian hilus cells (Leydig-like cells). J. clin. Endocr. 1953, 13, 139.

80. Dominguez, O. V., Samuels, L. T., and Huseby, R. A. Steroid biosynthesis in induced testicular interstitial cell tumors of mice. Ciba Found. Coll. Endocr. 1958, 12, 231.

81. Wilkins, L., and Cara, J. Further studies on the treatment of congenital adrenal hyperplasia with cortisone. V. Effects of cortisone therapy on testicular development. J. clin. Endocr. 1954, 14, 287. 